\title{
Nonhydrolysable Analogues of (p)ppGpp and (p)ppApp Alarmone Nucleotides as Novel Molecular Tools
}

\author{
Viktor Mojr, $\boldsymbol{\nabla}$ Mohammad Roghanian, $\boldsymbol{\nabla}$ Hedvig Tamman, $\boldsymbol{\nabla}$ Duy Dinh Do Pham, $\boldsymbol{\nabla}$ \\ Magdalena Petrová, Radek Pohl, Hiraku Takada, Katleen Van Nerom, Hanna Ainelo, \\ Julien Caballero-Montes, Steffi Jimmy, Abel Garcia-Pino,* Vasili Hauryliuk,** and Dominik Rejman*
}

Cite This: https://doi.org/10.1021/acschembio.1c00398

Read Online

ACCESS | Lلw Metrics \& More | 回 Article Recommendations | st Supporting Information

ABSTRACT: While alarmone nucleotides guanosine- $3^{\prime}, 5^{\prime}$-bisdiphosphate (ppGpp) and guanosine- $5^{\prime}$-triphosphate- $3^{\prime}$-diphosphate (pppGpp) are archetypical bacterial second messengers, their adenosine analogues ppApp (adenosine- $3^{\prime}, 5^{\prime}$-bisdiphosphate) and pppApp (adenosine- $5^{\prime}$-triphosphate- $3^{\prime}$-diphosphate) are toxic effectors that abrogate bacterial growth. The alarmones are both synthesized and degraded by the members of the RelA-SpoT Homologue ( $\mathrm{RSH}$ ) enzyme family. Because of the chemical and enzymatic liability of ( $\mathrm{p}$ )ppGpp and ( $\mathrm{p}$ )ppApp, these alarmones are prone to degradation during structural biology experiments. To overcome this limitation, we have established an efficient and straightforward procedure for synthesizing nonhydrolysable (p) $\mathrm{ppNu}_{\mathrm{N}} \mathrm{pp}$ analogues starting from $3^{\prime}$-azido-3'-deoxyribonucleotides as key intermediates. To demonstrate the utility of $(\mathrm{p}) \mathrm{ppG}_{\mathrm{N}} \mathrm{pp}$ as a molecular tool, we show that (i) as an $\mathrm{HD}$ substrate mimic, $\mathrm{ppG}_{\mathrm{N}} \mathrm{pp}$ competes with $\mathrm{ppGpp}$ to inhibit the enzymatic

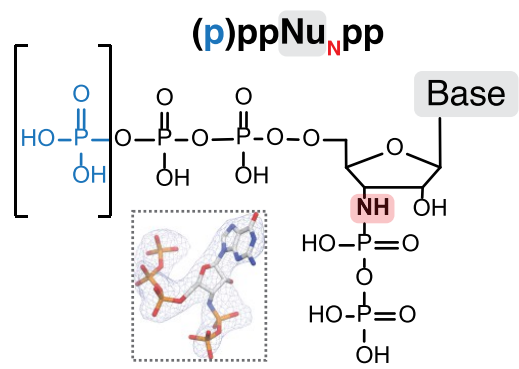

Base $=$ adenine $/$ guanine activity of human MESH1 Small Alarmone Hyrolase, SAH; and (ii) mimicking the allosteric effects of (p)ppGpp, ( $p$ )ppG $\mathrm{N}_{\mathrm{N}} \mathrm{pp}$ acts as a positive regulator of the synthetase activity of long ribosome-associated RSHs Rel and RelA. Finally, by solving the structure of the N-terminal domain region (NTD) of T. thermophilus Rel complexed with $\mathrm{pppG}_{\mathrm{N}} \mathrm{pp}$, we show that as an HD substrate mimic, the analogue serves as a bona fide orthosteric regulator that promotes the same intra-NTD structural rearrangements as the native substrate.

\section{INTRODUCTION}

Nucleotides guanosine- $3^{\prime}, 5^{\prime}$-bisdiphosphate (ppGpp) and guanosine- $5^{\prime}$-triphosphate- $3^{\prime}$-diphosphate (pppGpp) are archetypical second messengers in bacteria and chloroplasts. ${ }^{1-4}$ Members of the RelA-SpoT Homologue (RSH) enzyme family both synthesize these alarmones using GDP and GTP as substrates - and convert the alarmones back to GDP/GTP via the hydrolytic removal of the $3^{\prime}$ pyrophosphate group. ${ }^{5,6}$ By binding to numerous enzyme targets-either orthosterically (i.e., competing with substrates in the active site) or allosterically (i.e., to a dedicated regulatory site)-ppGpp and pppGpp control translation, transcription, replication, and metabolism.

Monofunctional (i.e., capable of only (p)ppGpp synthesis) RelA and bifunctional (i.e., capable of both (p)ppGpp synthesis and hydrolysis) Rel are the best mechanistically understood RSHs. Association with "starved" ribosomal complexes (i.e., stalled ribosomes with a vacant A-site supplemented with A-site-cognate deacylated tRNA) strongly stimulates the SYNTH activity of both RelA $^{8}$ and Rel. ${ }^{9}$ The synthesis activity of Escherichia coli RelA and Bacillus subtilis Rel is further stimulated by ppGpp and pppGpp, with the alarmones binding to a dedicated allosteric site located in the N-terminal enzymatic domain region, NTD, of the pro- tein. ${ }^{10-13}$ Structural, biochemical, and microbiological investigations of Rel enzymes have established that the enzymatic activities of synthesis (SYNTH) and hydrolysis (HD) domains directly oppose each other through an allosteric relay mechanism, ${ }^{12,14-16}$ which is exploited by the alarmone to activate the SYNTH activity. ${ }^{13}$ This toggling between closed $\mathrm{HD}^{\mathrm{ON}} \mathrm{SYNTH}^{\mathrm{OFF}}$ and open HD ${ }^{\mathrm{OFF}} \mathrm{SYNTH}^{\mathrm{ON}}$ states ensures that activation of SYNTH catalysis triggered by the "starved" ribosomes is coupled with efficient repression of $\mathrm{HD}$, thus preventing futile cycles of synthesis and hydrolysis of (p)ppGpp (Figure 1).

In addition to the ubiquitous long RSHs, bacteria also encode small monofunctional RSH enzymes that are involved in the control of alarmone nucleotides: small alarmone synthetases (SAS) and small alarmone hydrolases (SAH). ${ }^{17,18}$ Although no (p)ppGpp-synthesizing RSHs are encoded in animal genomes, ${ }^{5}$ animals do possess an $\mathrm{SAH}$

Received: May 28, 2021

Accepted: August 24, 2021 


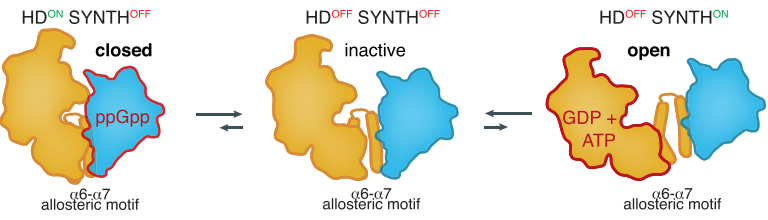

Figure 1. SYNTH-HD crosstalk within the N-terminal enzymatic domain region (NTD) controls the enzymatic output of bifunctional Rel enzymes. Enzymatic activity of bifunctional RSHs is controlled by the conformational state of the NTD region. When one catalytic site is engaged with substrate(s) and is enzymatically active, this allosterically inactivates the opposing catalytic domain, thus preventing futile cycles of synthesis and hydrolysis of the alarmone (panels right and left). The binding of substrates into both catalytic domains traps the enzyme in an intermediate conformational state in which neither of the active sites are catalytically competent (central panel).

enzyme, the Metazoan SpoT Homologue 1 (MESH1). ${ }^{19}$ While MESH1 can efficiently hydrolyze alarmones in a $\mathrm{Mn}^{2+}$ dependent manner, ${ }^{19,20}$ it was recently proposed to act as a $\mathrm{NADPH}$ phosphatase by catalyzing the removal of the $3^{\prime}$ phosphate moiety of NADPH. ${ }^{21}$ Recently, Ito and colleagues reported detection of $\mathrm{ppGpp}$ - but not pppGpp-in Drosophila and cultured human cells, ${ }^{22}$ thus reinvigorating the debate about the exact biological role of MESH1. However, given the preference of MESH1 for $\mathrm{pppGpp}^{20}$ and the lack of SYNTH-active RSHs in animals, ${ }^{5}$ further studies of proposed MESH1-mediated (p)ppGpp metabolism are necessary. In addition to the well-studied (p)ppGpp alarmones, recently the adenosine analogues ppApp (adenosine- $3^{\prime}, 5^{\prime}$-bisdiphosphate) and pppApp (adenosine-5' -triphosphate- 3 '-diphosphate) have stepped into the spotlight. First, toxic single-domain $\mathrm{RSH}$ enzymes were discovered to produce ( $\mathrm{p}$ )ppApp to abrogate bacterial growth. ${ }^{17,23}$ Second, representatives of several SAH subfamilies-including MESH1-were shown to efficiently hydrolyze (p)ppApp. . $^{1,20,24}$

Structural investigations of alarmone-bound $\mathrm{RSH}$ enzymes are complicated by, first, the rapid hydrolysis of the (p)ppGpp to GDP/GTP by HD-competent RSHs, second, the nonenzymatic degradation of the alarmone resulting in partially hydrolyzed ppG2'3'p. ${ }^{14}$ While it is possible to use enzymes from thermophilic bacteria-such as Thermus thermophilus Rel $\left(\mathrm{Rel}_{T t}\right)$, an extremely inefficient (p)ppGpp-hydrolase at $\mathrm{RT}^{16,25}$ - studies of enzymes from mesophilic species remain challenging. To address these experimental challenges, we drew inspiration from the application of nonhydrolysable GTP analogues such as $5^{\prime}$-guanylyl imidodiphosphate (GppNHp) a molecular tool that has revolutionized structural and biochemical studies of GTPases ${ }^{26-29}$ - to develop nonhydrolysable (i.e., resistant to degradation by HD-competent RSHs) (p)ppNupp alarmone analogues.

Just as Rel RSHs toggle between $\mathrm{HD}^{\mathrm{ON}} \mathrm{SYNTH}^{\mathrm{OFF}}$ and $\mathrm{HD}^{\mathrm{OFF}} \mathrm{SYNTH}^{\mathrm{ON}}$ states, GTPases toggle between GTPbound ON state, and GDP-bound OFF state, with the ligands-both GDP/GDP nucleotides and macromolecules binding the GTPase-regulating the switch. ${ }^{28,30}$ Importantly, in the case of translational GTPases-i.e. GTPases involved in protein synthesis ${ }^{31}$ — the nonhydrolysable nucleotide GppNHp has a significantly lower affinity to GTPase than GTP and is unable to promote the ON/OFF transition. ${ }^{28,29,32,33}$ The reason being that while GTP efficiently coordinates a crucial

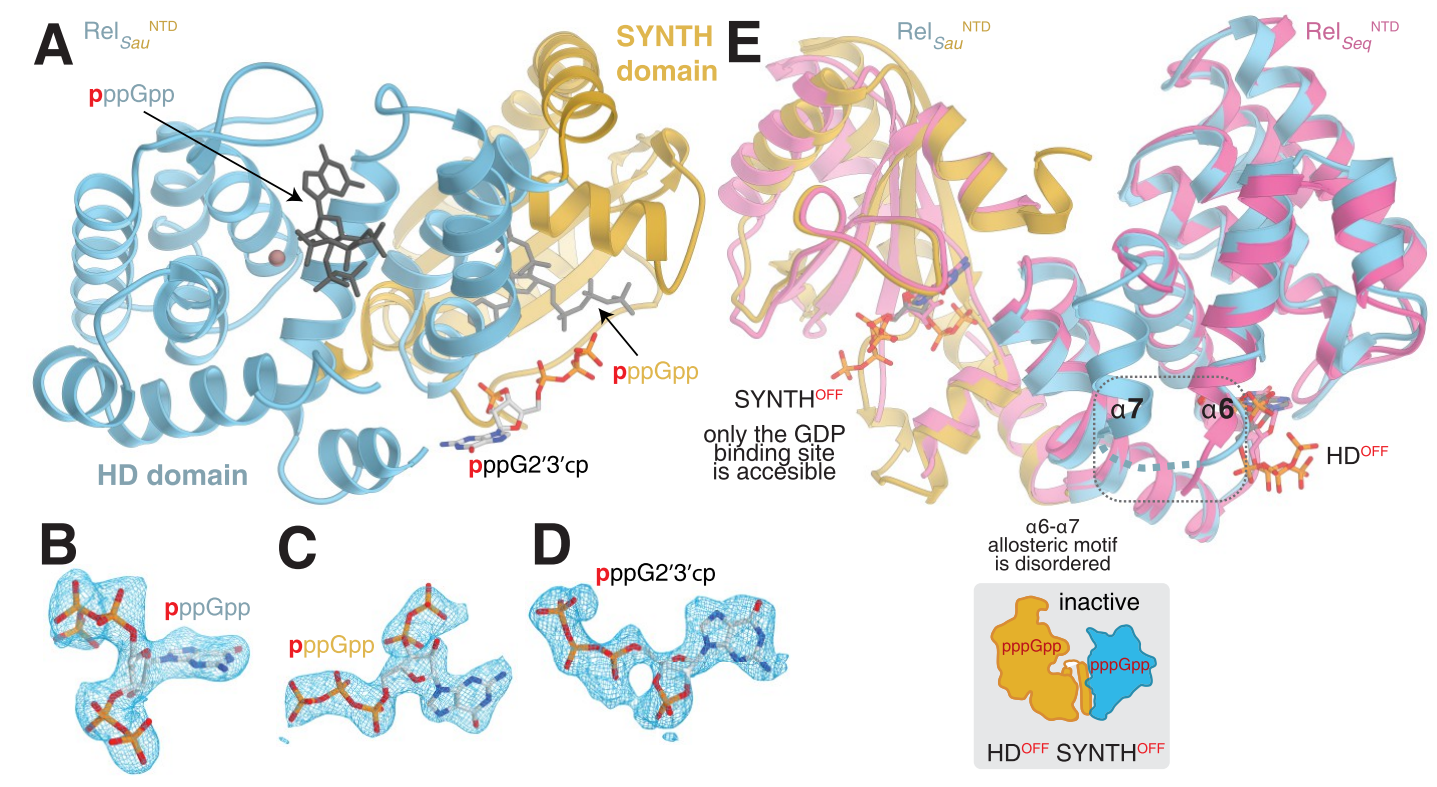

Figure 2. Structure of $S$. aureus Rel NTD in complex with pppGpp. (A) Crystal structure of Rel ${ }_{\text {Sau }}^{\text {NTD }}$ soaked with pppGpp (PDBID 7OIW). The crystals were rapidly soaked with nonphysiologically high concentration $(50 \mathrm{mM})$ of pppGpp in an attempt to overcome the intrinsic hydrolytic activity of Rel Sau $_{\text {NTD }}$. Density for pppGpp (colored in dark gray) was observed in both active sites. In addition, a partially hydrolyzed pppG2' $3^{\prime}$ cp cyclic product (shown in atom colors), which underscores the issues associated with soaking with substrates, was also observed bound to the enzyme forming a crystallographic contact. The result of both active sites occupied simultaneously by pppGpp is the entrapment of the enzyme in an inactive $\mathrm{HD}^{\mathrm{OFF}}$ SYNTH ${ }^{\mathrm{OFF}}$ state with both active sites being catalytically incompetent. Electron density map representation (blue mesh) of pppGpp in the HD active site (B), in the SYNTH active site (C), and the electron density map representation (blue mesh) of pppG2' $3^{\prime} \mathrm{cp}$ in the

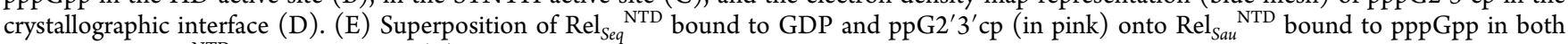
active sites. $\operatorname{Rel}_{\text {Sau }}{ }^{\mathrm{NTD}}$ is colored as per (A). The comparison highlights that the simultaneous binding to each catalytic domain locks the enzyme in a $\mathrm{HD}^{\mathrm{OFF}}$ SYNTH ${ }^{\mathrm{OFF}}$ inactive state in which the ATP-binding site of the SYNTH domain is occluded, and the HD active site is partially disordered. 
Scheme 1. Retrosynthetic Scheme for $(\mathrm{p}) \mathrm{ppNu}_{\mathrm{N}} \mathrm{pp}^{a}$
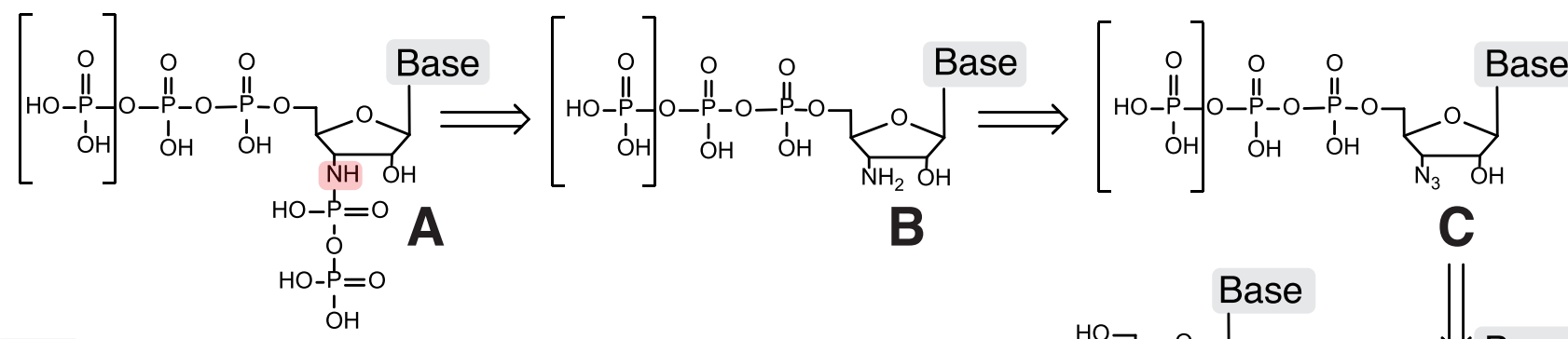

Base $=$ adenine $/$ guanine

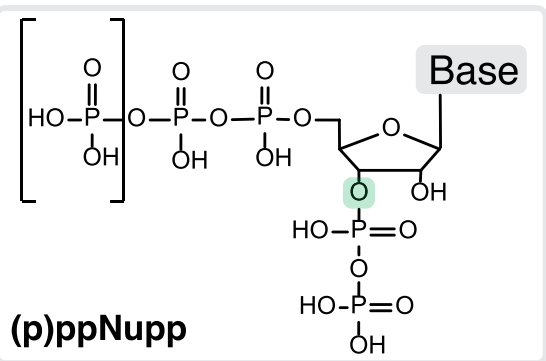

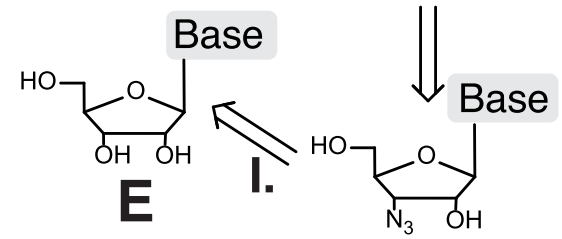
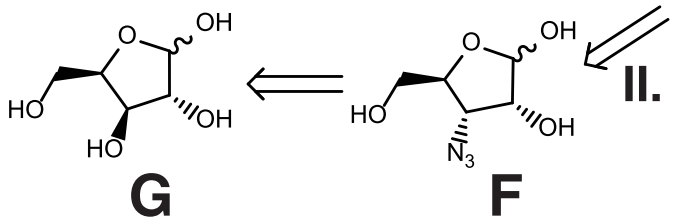

D

\begin{abstract}
${ }^{a} \mathbf{A} \rightarrow \mathbf{B}$ disconnection of the bond between the phosphorus atom and the $3^{\prime}$ nitrogen atom: reaction of inorganic pyrophosphate with $3^{\prime}$-amino- $3^{\prime}$ deoxynucleotide (the chemical reaction is shown in Figure 4). B $\rightarrow \mathbf{C}$ conversion of the azido group to amino group via catalytic hydrogenation (see Scheme 2). C $\rightarrow$ D disconnection of the $\mathrm{P}-\mathrm{O}$ bond in the $5^{\prime}$ position of $3^{\prime}$-azido-3'-deoxynucleoside: either the Yoshikawa procedure for triphosphate formation or reaction via phosphomorpholidate obtained from H-phosphonate (see Scheme 2). D $\rightarrow$ E replacement of the $3^{\prime}$-hydroxy group with the 3'-azido group. This complex multistep reaction is described in detail in Supporting Information (Supplementary Schemes S1 and S2). D $\rightarrow$ F detachment of the nucleobase from 3-azidoribose (Supplementary Scheme S3). F $\rightarrow$ G transformation of D-xylose to 3-azidoribose, described in detail in Supporting Information (see Supplementary Scheme S3). The experimental procedures for the synthesis of (p)ppG $\mathbf{N}_{\mathrm{N}} \mathbf{p}$ are described in the main text Methods section, while procedures for the synthesis of ( $\mathbf{p}) \mathbf{p} \mathbf{p} \mathbf{A}_{\mathbf{N}} \mathbf{p p}$ are described in Supporting Information.
\end{abstract}

monovalent $\mathrm{K}^{+}$cation in the GTPase active site, GppNHp does not. ${ }^{34}$ Analogously, a $\mathrm{Mn}^{2+}$ ion coordinated in the $\mathrm{RSH}$ HD active site is essential for catalysis and conformational switching. ${ }^{14,16,24}$ Therefore, in order to establish that nonhydrolysable alarmone nucleotide analogues are reliable (p)ppGpp mimics, it is essential to validate that these molecular tools coordinate crucial metal ions and promote conformational switching of RSHs similarly to the natural compounds.

Here we report an efficient and versatile synthetic route for (p)ppNupp alarmone analogues. By analogy with GppNHp, $3^{\prime}$-oxygen atom of ( $\mathrm{p}$ )ppNupp was replaced with a nitrogen atom to render the compounds resistant to hydrolyzing enzymes that break the $3^{\prime}-\mathrm{P}-\mathrm{O}$ bond. The target compounds were (i) $3^{\prime}$-amino-3'-deoxy-guanosine $5^{\prime}$-diphosphate- $3^{\prime}$-diphosphate (ppG $\left.\mathrm{p}_{\mathrm{N}} \mathrm{pp}\right),(\mathrm{ii}) 3^{\prime}$-amino-3'-deoxy-guanosine $5^{\prime}$ triphosphate-3'-diphosphate $\mathbf{p p p} \mathrm{G}_{\mathrm{N}} \mathrm{pp}$, (iii) $3^{\prime}$-amino- $3^{\prime}$-deoxyadenosine $5^{\prime}$-diphosphate- $3^{\prime}$-diphosphate $\mathbf{p p A _ { N }} \mathbf{p p}$, and (iv) 3'-amino-3'-deoxyadenosine $5^{\prime}$-triphosphate- $3^{\prime}$-diphosphate $\mathbf{p p p A}_{\mathrm{N}}$ pp. (p)ppNupp analogues were prepared from key intermediates $3^{\prime}$-azido- $3^{\prime}$-deoxyribonucleotides in four steps. $3^{\prime}$-Azido- $3^{\prime}$-deoxyguanosine was prepared from guanosine in 11 steps or from D-xylose in 9 steps and $3^{\prime}$-azido-3'deoxyadenosine was prepared from D-xylose in 8 steps. The subsequent important step that we developed is the attachment of the $\mathrm{H}$-phosphonate moiety to the nucleoside 5 '-position via reaction of tris $(1,1,1,3,3,3$-hexafluoroisopropyl)phosphite with unprotected nucleoside (avoiding complex protection scheme) followed by installing remaining phosphates in a sequential manner. All the final products were obtained in $>95 \%$ purity using a combination of ion exchange chromatography on Poros HQ50 and preparative HPLC on reversed phase. We have characterized the effects of $\mathbf{p p G}_{\mathrm{N}} \mathrm{pp}$ and $\mathrm{pppG}_{\mathrm{N}} \mathrm{pp}$ on $\mathrm{SAH}$ MESH1, as well as long RSHs RelA and Rel through biochemical, biophysical, and X-ray crystallography approaches, and we have verified their functionality as nonhydrolysable ( $\mathrm{p}$ )ppGpp mimics of allosteric regulators, HD substrates as well as SYNTH products.

\section{RESULTS AND DISCUSSION}

Native (p)ppGpp Is Poorly Suited for X-ray Studies of Mesophilic Rel Enzymes. To gain mechanistic insights into the mechanism of alarmone-mediated regulation of $\mathrm{RSH}$ enzymes, it is essential to solve structures of these enzymes in complex with the alarmone. The mesophilic Rel enzyme from Staphylococcus aureus $\left(\operatorname{Rel}_{\text {Sau }}\right.$ ) is expected to rapidly degrade the alarmone at RT. We crystallized the hydrolysis-competent NTD region of the enzyme ( $\operatorname{Rel}_{\text {Sau }}{ }^{\mathrm{NTD}}$ ) and attempted soak-in experiments. In an attempt to overcome the enzymatic degradation of the alarmone, we used short soaking times (below $20 \mathrm{~s}$ ) and a nonphysiologically high concentration of pppGpp $(50 \mathrm{mM})$. This resulted in simultaneous nonproductive binding of the alarmone to both $\mathrm{HD}$ and SYNTH active sites, which locked the enzyme in an intermediate state rendering both active sites catalytically incompetent (Figure $2 \mathrm{~A}-\mathrm{C}$ ). The resulting complex resembles the $\mathrm{HD}^{\mathrm{OFF}}$ SYNTH ${ }^{\mathrm{OFF}}$ state (Figure 1, central panel) that was previously observed in the structure of Streptococcus dysgalactiae subsp. equisimilis Rel NTD $\left(\operatorname{Rel}_{S e q}{ }^{\mathrm{NTD}}\right.$ ) in complex with ppG2' $3^{\prime} \mathrm{cp}$ and $\mathrm{GDP}^{14}$ and the unbound $\mathrm{Rel}_{T t}{ }^{\mathrm{NTD}}$, in which neither active site is fully compatible with catalysis. ${ }^{16}$ In this state, the HD active site is partially disordered. The crucial $\alpha 6-\alpha 7$ motif that contains several active site residues is disordered in both $\operatorname{Rel}_{S e q}{ }^{\text {NTD }}$ and $\operatorname{Rel}_{S a u}{ }^{\text {NTD }}$, and the ED motif 

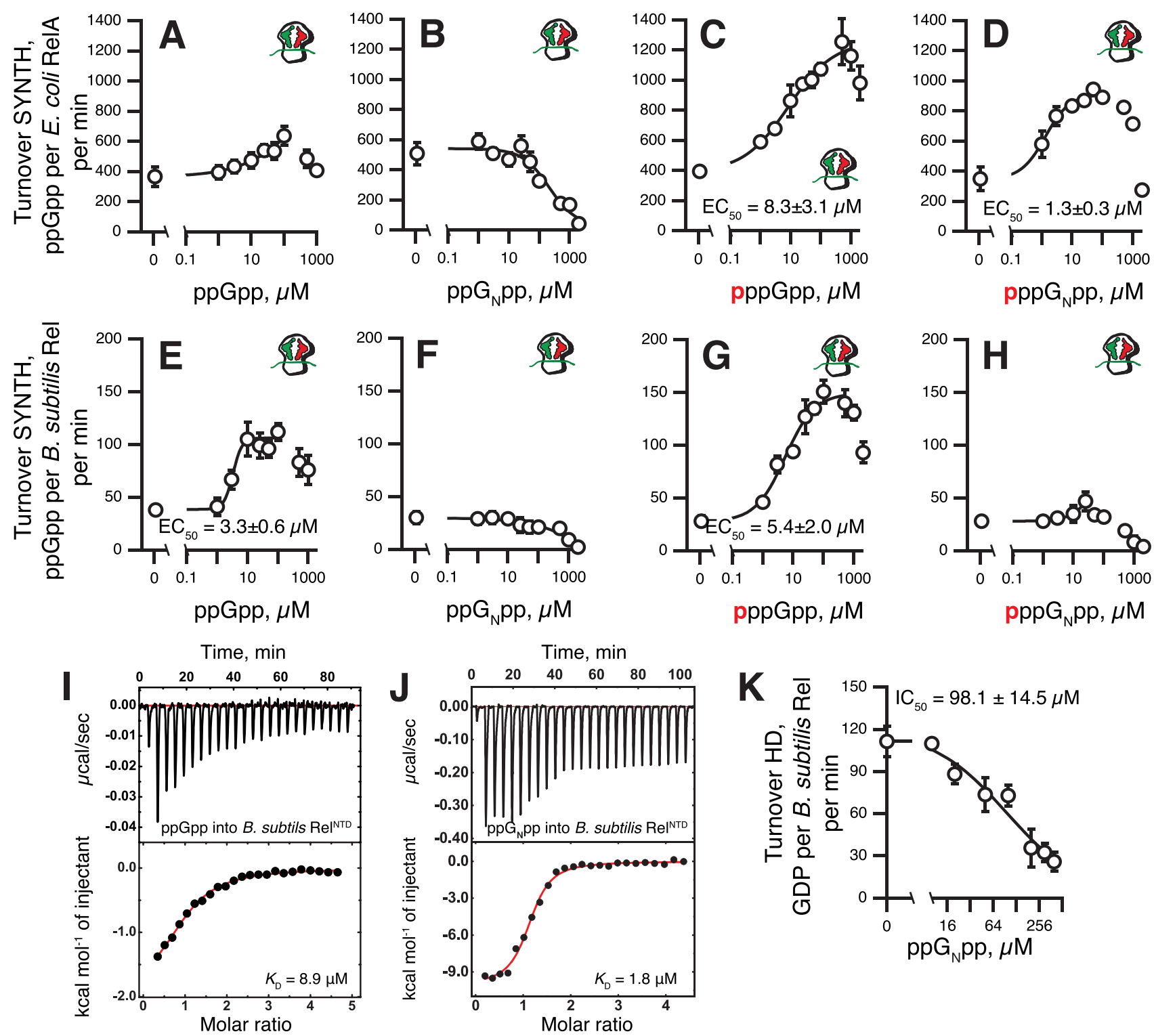

Figure 3. Effects of the alarmones and their nonhydrolysable analogues on enzymatic activities of E. coli RelA and B. subtilis Rel. (A-D) Effects of the alarmones and their nonhydrolysable analogues on ppGpp synthesis activity of $E$. coli RelA. The reaction mixtures contained $300 \mu \mathrm{M}{ }^{3} \mathrm{H}$ GDP, $1 \mathrm{mM}$ ATP, $2 \mu \mathrm{M}$ E. coli deacylated tRNA ${ }^{\mathrm{Val}}$, $30 \mathrm{nM}$ RelA $\mathrm{Ec}_{\mathcal{c}} 0.25 \mu \mathrm{M}$ E. coli initiation complexes $70 \mathrm{~S}$ IC(MVF), as well as increasing concentrations of alarmones. $(\mathrm{E}-\mathrm{H})$ Effects of the alarmones and their nonhydrolysable analogues on ppGpp synthesis activity of Rel $\mathrm{Bsu}_{\text {su }}$. The reaction mixtures contained $300 \mu \mathrm{M}^{3} \mathrm{H}$ GDP, $1 \mathrm{mM}$ ATP, $2 \mu \mathrm{M}$ E. coli deacylated tRNA ${ }^{\mathrm{Val}}, 30 \mathrm{nM} \mathrm{Rel}_{B s w} 0.25 \mu \mathrm{M}$ B. subtilis initiation complexes $70 S$ IC(MVF), as well as increasing concentrations of alarmones. Error bars represent standard deviations of the turnover estimates by linear regression. Binding of ppGpp (I) and $\mathbf{p p G}_{\mathrm{N}} \mathrm{pp}(\mathrm{J})$ to $\operatorname{Rel}_{B s u}{ }^{\mathrm{NTD}}$, monitored by isothermal titration calorimetry. (K) Inhibition of ${ }^{3} \mathrm{H}$ ppGpp hydrolysis by $\operatorname{Rel}_{B s u}$ by $\mathrm{ppG}_{\mathrm{N}} \mathrm{pp}$. Reaction mixtures contained $250 \mathrm{nM} \mathrm{Rel}_{B s u}, 300 \mu \mathrm{M}^{3} \mathrm{H}$ ppGpp, and increasing concentrations of ppG $\mathrm{G}_{\mathrm{N}} \mathrm{pp}$. Enzymatic experiments were performed at $37^{\circ} \mathrm{C}$ in HEPES:Polymix buffer ( $5 \mathrm{mM} \mathrm{Mg}^{2+}$ final concentration), additionally supplemented with 1 $\mathrm{mM} \mathrm{Mn}{ }^{2+}$ in the case of hydrolysis assays. Error bars represent standard deviations of the turnover estimates by linear regression.

of the $\mathrm{HD}$ active site that is essential for catalyzing the nucleophilic attack to the 3 -pyrophosphate is directed away from the active site. In addition, the SYNTH active site is partially occluded by the HD domain, with only the GDP binding site accessible (Figure 2D). Moreover, we also observed a partially hydrolyzed product, pppG2' $3^{\prime} \mathrm{cp}$, at the crystallographic interface formed by two $\operatorname{Rel}_{\text {Sau }}$ NTD proteins in the crystal packing (Figure 2E). Given that intact (p)ppGpp fails to persist long enough in the active site of Rel from mesophilic bacteria to trigger the relevant active conformation, we conclude that the native alarmones are ill-suited ligands for structural biology.

Synthesis of $p p G_{N} p p, p p p G_{N} p p, p p A_{N} p p$, and $p_{p p A_{N}}$ pp. To overcome the lability of natural alarmones, we set out to develop a synthetic route for production of their nonhydrolyzable analogues, (p) pp $\mathrm{Nu}_{\mathrm{N}} \mathbf{p p}$. Retrosynthetic analysis for $(\mathrm{p}) \mathrm{ppNu} \mathrm{Nu}_{\mathrm{N}} \mathrm{pp}$ preparation is shown in Scheme 1 . The disconnection of the $\mathrm{P}-\mathrm{N}$ bond in the $3^{\prime}$ position of target $(\mathrm{p}) \mathbf{p p N u _ { \mathrm { N } }} \mathrm{pp}$ A leads to the aminonucleotide $\mathbf{B}$, which could be formed from azidonucleotide $\mathbf{C}$. Disconnection of the pyrophosphate $\mathrm{P}-\mathrm{O}$ bond in the $5^{\prime}$ position results in 
Scheme 2. Synthesis of (p)ppNuNpp ${ }^{a}$

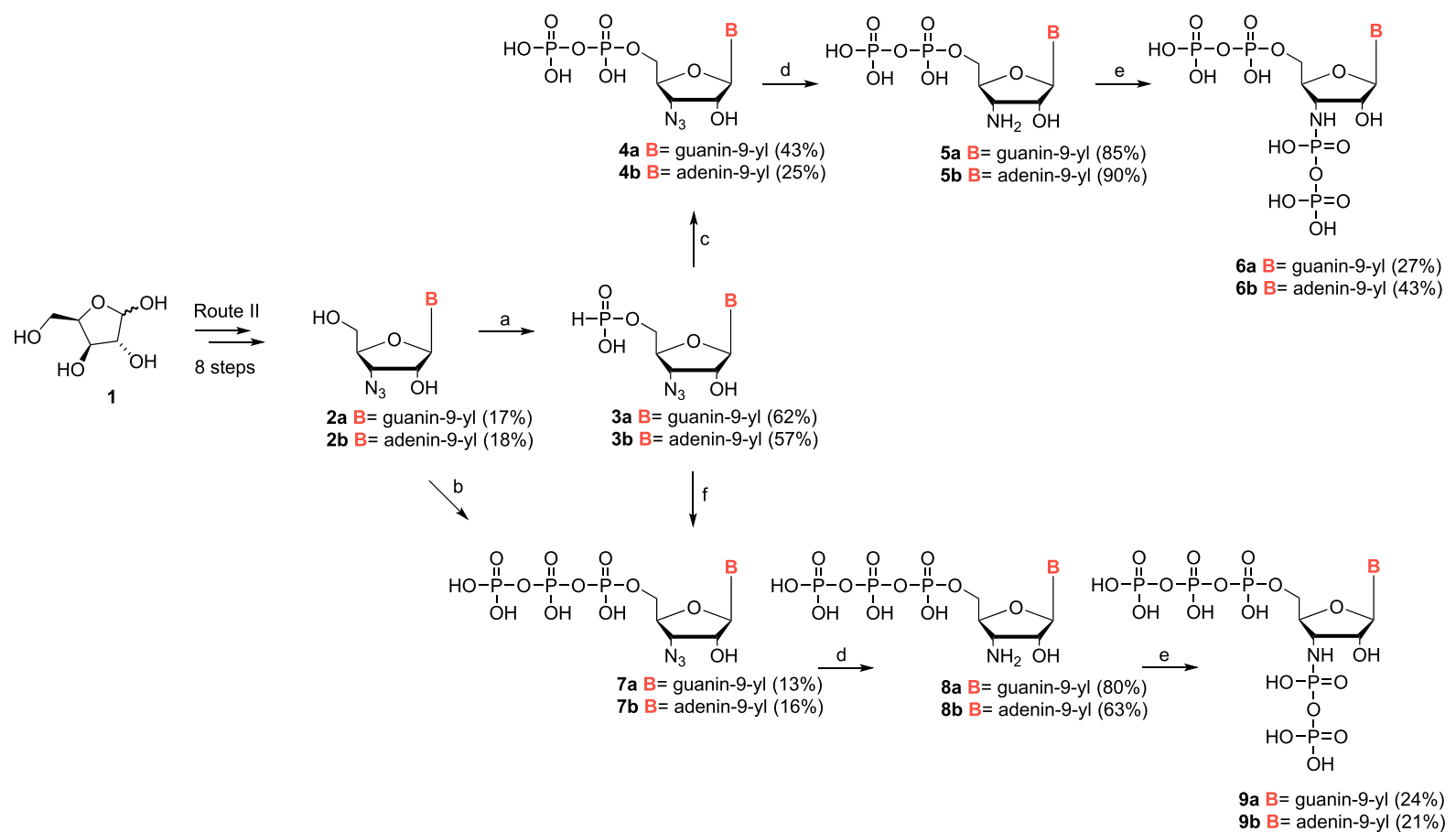

${ }^{a}$ Reagents and conditions: (a) tris(1,1,1,3,3,3-hexafluoropropan-2-yl) phosphite, DIPEA, DMF. (b) $\mathrm{POCl}{ }_{3}, \mathrm{P}(\mathrm{O})\left(\mathrm{OCH}_{3}\right)_{3}$, followed by $\left(\mathrm{Bu}_{3} \mathrm{~N}\right)_{3} \mathrm{HP}_{2} \mathrm{O}_{7}$ in DMF. (c) trimethylsilylmorpholine, $\mathrm{MeCN}$; room temperature, then $\mathrm{CCl}_{4}$, followed by $\left(\mathrm{Bu}_{3} \mathrm{~N}\right)_{2} \mathrm{HPO} \mathrm{O}_{4}, \mathrm{DMF}$. $(\mathrm{d}) \mathrm{H}_{2}, \mathrm{Pd} / \mathrm{C}$, $\mathrm{H}_{2} \mathrm{O}$; (e) $\mathrm{Na}_{4} \mathrm{P}_{2} \mathrm{O}_{7}, 100 \mathrm{mM}$ MES, EDC, water. (f) trimethylsilylmorpholine, $\mathrm{MeCN}$; room temperature, then $\mathrm{CCl}_{4}$, followed by $\left(\mathrm{Bu}_{3} \mathrm{~N}\right)_{3} \mathrm{HP}_{2} \mathrm{O}_{7}$ in DMF.

azidonucleoside $\mathbf{D}$. Azidonucleoside $\mathbf{D}$ can be prepared either by installation of an azido group on ribonucleoside $\mathbf{E}$ (Route I) ${ }^{35,36}$ or by attachment of a nucleobase (nucleosidation reaction) to azidosugar $\mathbf{F}$ prepared from $D$-xylose $\mathbf{G}$ (Route II). ${ }^{37}$ We have evaluated both Route I (detailed description is provided in Supporting Information, see Supplementary Schemes S1 and S2) and Route II (Scheme S3) for the synthesis of $3^{\prime}$-azido-3'-deoxyguanosine (compound $\mathbf{D}^{\text {Gua }}$, Figure 3). While Route I consists of 11 steps and results in a mere $3 \%$ overall yield, Route II afforded target $3^{\prime}$-azido- $3^{\prime}$ deoxyguanosine (2a) in $18 \%$ yield and $3^{\prime}$-azido- $3^{\prime}$-deoxyadenosine (2b) in $17 \%$ yield over 8 steps (Scheme 2) from Dxylose (1) according to published procedure. ${ }^{37}$ The transformation of azidonucleosides $2 \mathrm{a}-\mathrm{b}$ to $(\mathrm{p}) \mathrm{ppNu} \mathrm{pu}_{\mathrm{N}} \mathrm{pp}$ species was accomplished using the same synthetic steps regardless of the nucleobase. The experimental procedure for the synthesis of $(p) p_{p} G_{N} p p$ is described in the main text Methods section, whereas the procedure for the synthesis of $(\mathbf{p}) \mathbf{p p A _ { N }} \mathbf{p p}$ is described in Supporting Information.

The next step was the introduction of the phosphate moiety to 5 -position of prepared nucleosides. To avoid complex protection/deprotection scheme, we attempted to prepare $\mathrm{H}$ phosphonates $\mathbf{3 a}-\mathbf{b}$ directly from unprotected nucleosides $\mathbf{2} \mathbf{a}-\mathbf{b}$ (Scheme 2). Using DMF as a solvent and carrying the reaction with tris $(1,1,1,3,3,3$-hexafluoropropan-2-yl)phosphite $^{38}$ at lower temperature (approximately $-5{ }^{\circ} \mathrm{C}$ ), we were able to isolate desired $5^{\prime}$-H-phosphonates selectively with $\approx 60 \%$ yields after column chromatography on silica gel. $\mathrm{H}$ phosphonates were then successfully converted to diphosphates $\mathbf{4} \mathbf{a}-\mathbf{b}$ and triphosphate $7 \mathbf{b}$ via in situ-generated morpholidates, and the adenosine triphosphate $7 \mathbf{a}$ was prepared using Yoshikawa procedure ${ }^{39}$ from 2b. 3'-Azido groups were hydrogenated over palladium on charcoal to afford $3^{\prime}$-aminoderivatives $\mathbf{5 a}-\mathbf{b}$ and $\mathbf{8 a}-\mathbf{b}$. Finally, $3^{\prime}$ aminonucleotides $\mathbf{5 a}-\mathbf{b}$ and $\mathbf{8} \mathbf{a}-\mathbf{b}$ were converted to target $\mathrm{ppG}_{\mathrm{N}} \mathrm{pp}(6 \mathrm{a}), \mathrm{pppG}_{\mathrm{N}} \mathrm{pp}$ (9a), $\mathrm{ppA}_{\mathrm{N}} \mathrm{pp}$ (6b), and $\mathrm{pppA}_{\mathrm{N}} \mathrm{pp}$ (9b) by reaction with potassium pyrophosphate in the presence of MES ( $(N$-morpholino)ethanesulfonic acid) in water and catalyzed by soluble carbodiimide EDC (1-ethyl-3(3-(dimethylamino)propyl)carbodiimide hydrochloride). ${ }^{40}$ In order to avoid the decomposition of the desired product, it is essential that upon completion of the reaction the sample should be applied onto the column without evaporation. All nucleoside polyphosphates, including final products, were obtained in pure form using combination of preparative $\mathrm{RP}$ HPLC (using gradient of $\mathrm{MeOH}$ in $0.1 \mathrm{M}$ aq. TEAB) and ion exchange chromatography on Poros 50HQ (using a linear gradient of $1 \mathrm{M}$ TEAB in $\mathrm{H}_{2} \mathrm{O}$ ).

Evaluation of $p p G_{N} p p$ and $p p p G_{N} p p$ as Stable Alarmone Analogues for Investigation of the Allosteric Control of Rel/RelA Synthetase Activity. To assess the suitability of the analogues as molecular tools to study Rel/ RelA activation by alarmones, we compared the effects of

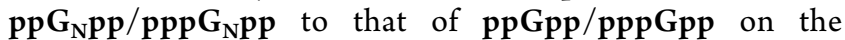
synthesis activity of full-length $E$. coli RelA $\left(\operatorname{RelA}_{E c}\right)$ and $B$. subtilis $\operatorname{Rel}\left(\operatorname{Rel}_{B s u}\right)$ in our reconstituted biochemical system (Figure $3 \mathrm{~A}-\mathrm{H}) .{ }^{41,42}$ We followed ${ }^{3} \mathrm{H}$ ppGpp synthesis by RelA or Rel in the presence of (i) $70 \mathrm{~S}$ ribosomal initiation complexes (70S IC) prepared from either E. coli or B. subtilis ribosomes, (ii) A-site-cognate deacylated E. coli tRNA ${ }^{\text {Val }}$, as well as (iii) increasing concentrations of the alarmones.

At low concentrations, ppGpp and pppGpp specifically bind to the allosteric site and stimulate the synthesis activity of both $\operatorname{RelA}_{E c}$ (Figure 3A,C) and $\operatorname{Rel}_{B s u}$ (Figure 3E,G). Conversely, 

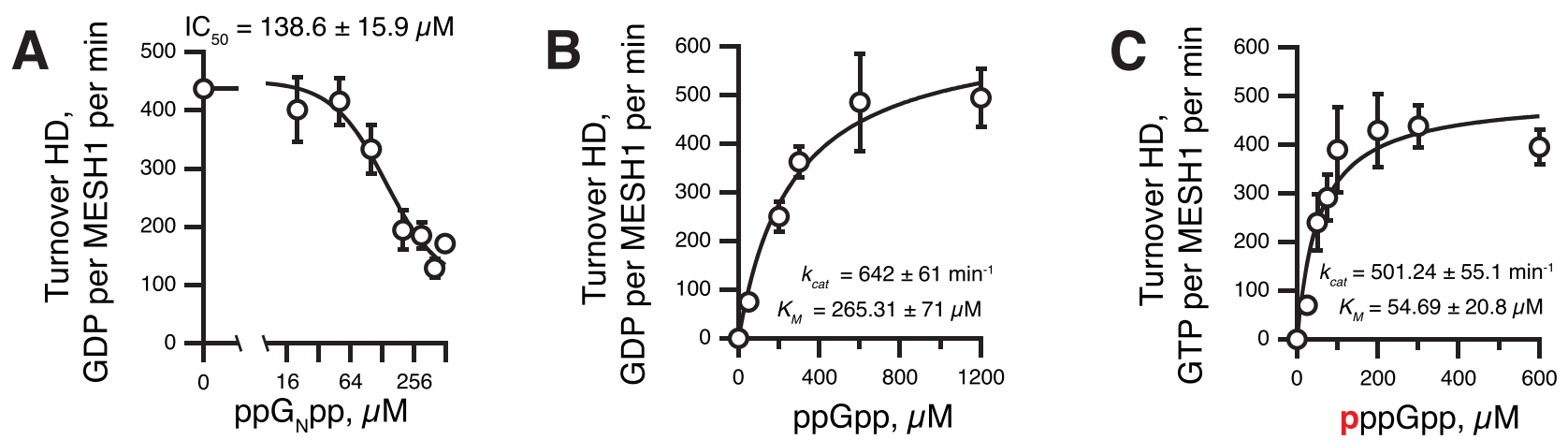

Figure 4. Biochemical analysis of MESH1:ppG ${ }_{\mathrm{N}} \mathrm{pp}$ interaction. (A) Inhibition of ${ }^{3} \mathrm{H}$ ppGpp hydrolysis by human $\mathrm{MESH}$ by $\mathrm{ppG} \mathrm{G}_{\mathrm{N}} \mathrm{pp}$. Reaction mixtures contained $100 \mathrm{nM}$ MESH1, $300 \mu \mathrm{M}{ }^{3} \mathrm{H}$ ppGpp and increasing concentrations of $\mathbf{p p G}_{\mathrm{N}} \mathbf{p p}$. The experiments were performed at $37^{\circ} \mathrm{C}$ in HEPES:Polymix buffer ( $5 \mathrm{mM} \mathrm{Mg}{ }^{2+}$ final concentration) additionally supplemented with $1 \mathrm{mM} \mathrm{Mn^{2+ }}$. Error bars represent standard deviations of the turnover estimates by linear regression. Michaelis-Menten analysis of human MESH1 ppGpp (B) and pppGpp (C) hydrolysis activities.

when added in excess of $100 \mu \mathrm{M}$, the alarmones start inhibiting the enzymes, most likely by binding to the active site and competing with the GDP/GTP substrate. As we reported earlier, ${ }^{11-13}$ pppGpp is a significantly stronger allosteric regulator than ppGpp (compare Figure $3 \mathrm{~A}, \mathrm{C}$ as well as Figure $3 \mathrm{E}, \mathrm{G})$. Note that since ${ }^{3} \mathrm{H}$ ppGpp is produced by $\operatorname{RelA}_{E c}$ and $\operatorname{Rel}_{B s u}$ in situ during the reaction, the in situ-generated alarmone could mask the effect of ppGpp added in trans, thus resulting in our enzymatic assays underestimating the strength of ppGpp's stimulatory effect.

Nonhydrolysable $\mathbf{p p p G}_{\mathrm{N}} \mathbf{p p}$ strongly activates E. coli RelA's SYNTH activity (Figure 3D) and has a weak but detectable stimulatory effect on Rel (Figure $3 \mathrm{H}$ ). Importantly, as compared with pppGpp, the analogue is a stronger inhibitor at higher concentrations, suggesting tighter nonproductive secondary association with the SYNTH active site of the enzyme. At the same time, $\mathbf{p p p G _ { N }} \mathbf{p p}$ also seems to have a moderately higher affinity to the allosteric site as well, as evident from the lower $\mathrm{EC}_{50}$ as compared with pppGpp itself $(1.3 \pm 0.3 \mu \mathrm{M}$ vs $8.3 \pm 3.1 \mu \mathrm{M}$, Figure $3 \mathrm{C}, \mathrm{D})$. An even stronger tendency for inhibition was observed for $\mathbf{p p G}_{\mathrm{N}} \mathbf{p p}$ (Figure 3B,F), which results in complete masking of the stimulatory effect. Using isothermal titration calorimetry (ITC), we quantified the affinities of $\mathbf{p p G p p}$ and $\mathbf{p p G}_{\mathrm{N}} \mathbf{p p}$ to the B. subtilis Rel NTD fragment $\left(\operatorname{Rel}_{B s u}{ }^{N T D}\right)$. Our ITC experiments monitor the alarmone's binding to the highaffinity allosteric site, since the active sites have a relatively low affinity to the alarmone acting as a product (SYNTH site) or substrate (HD site). ${ }^{12} \mathbf{p p G}_{\mathrm{N}} \mathbf{p p}$ has approximately 5 -fold higher affinity to $\operatorname{Rel}_{B s u}$ NTD than ppGpp (Figure $3 \mathrm{I}, \mathrm{J}$ ). We concluded that $\mathbf{p p p G}_{\mathrm{N}} \mathrm{pp}$ is a useful molecular tool for studies of the allosteric control of Rel/RelA by the alarmones. However, one should be cautious when interpreting the results obtained with $\mathbf{p p G}_{\mathrm{N}} \mathbf{p p}$ as its binding to the active site potentially masks the allosteric regulatory effects.

Evaluation of $p p G_{N} p p$ and $p p p G_{N} p p$ as Substrate Analogues for Structural Studies of HD-Competent RSH Enzymes. $\mathbf{p p G}_{\mathrm{N}} \mathrm{pp}$ and $\mathrm{pppG}_{\mathrm{N}} \mathrm{pp}$ are promising nonhydrolysable substrates analogues for structural studies of RSH hydrolases. We tested whether nonhydrolysable alarmone analogues are efficient competitors of the ppGpp substrate and thus are suitable for structural studies of $\mathrm{RSH}$ hydrolysis activity. $\mathbf{p p G}_{\mathrm{N}} \mathbf{p p}$ efficiently inhibits ${ }^{3} \mathrm{H}$ ppGpp hydrolysis by $\operatorname{Rel}_{B s u}$ (Figure 3K) as well as by human MESH1 (Figure 4A), suggesting that the analogue has relatively higher affinity for the hydrolysis active site of the RSHs than the native ppGpp substrate. In agreement with an earlier report, ${ }^{20}$ we find that the MESH1 hydrolase activity displays a preference for the pppGpp substrate over ppGpp: while the $k_{\text {cat }}$ for ppGpp and pppGpp are similar, $K_{M}$ for pppGpp is lower compared with ppGpp, indicating a higher affinity to the more charged substrate (Figure 4B,C).

To gain structural insight into the mode of binding of the nonhydrolysable alarmones and the effects of the oxygen substitution in the interaction with the enzyme, we cocrystallized $\mathbf{p p p G} \mathbf{G}_{\mathrm{N}} \mathbf{p p}$ with T. thermophilus $\operatorname{Rel}^{\mathrm{NTD}}\left(\operatorname{Rel}_{T t}{ }^{\mathrm{NTD}}\right.$ ) (Figure 5). The $\mathbf{p p p G _ { N }}$ pp-bound $\operatorname{Rel}_{T t}{ }^{\mathrm{NTD}}$ assumes the same closed $\mathrm{HD}^{\mathrm{ON}} \mathrm{SYNTH}^{\mathrm{OFF}}$ state earlier observed in the case of the $\mathrm{Rel}_{T t}{ }^{\text {NTD }}: \mathbf{p p G p p}$ complex ${ }^{16}$ (Figure 5). In the $\mathrm{Rel}_{T t}{ }^{\mathrm{NTD}}$ :pppG $\mathrm{G}_{\mathrm{N}} \mathbf{p p}$ complex obtained at $20^{\circ} \mathrm{C}$, all the residues essential for catalysis by the $\mathrm{HD}$ active site are arranged analogously to those in the $\operatorname{Rel}_{T t}{ }^{\mathrm{NTD}}: \mathrm{ppGpp}$ complex obtained at $4{ }^{\circ} \mathrm{C}$, with $\mathrm{pppG}_{\mathrm{N}} \mathrm{pp}$ bound in the same orientation as ppGpp. The very presence of intact $p_{p p G_{N}} p p$ in catalytic site of the HD domain is the direct proof of the nonhydrolysable analogue being resistant to cleavage by $\mathrm{HD}$-active RSHs. Importantly, the $\mathrm{Mn}^{2+}$ coordination is exactly the same as that observed in the $\operatorname{Rel}_{T t}^{\mathrm{NTD}}$ :ppGpp complex, and the presence of the nonhydrolysable ligand in the active site triggered the full allosteric signaling of the NTD that results in occlusion of the SYNTH site observed in $\operatorname{Rel}_{T t}{ }_{T t}$. The comparison of the two structures shows the nonhydrolysable nature of the alarmone has no major structural effects, with only small deviations observed at the $5^{\prime}$-polyphosphate moiety because of the extra phosphate in $\mathbf{p p p G}_{\mathrm{N}} \mathbf{p p}$ as compared with $\mathbf{p p G p p}$.

The nonhydrolysable alarmone analogues presented here have multiple future applications. These include-but are not limited to-structural studies of RSH enzymes, such as X-ray crystallography, cryo-EM, and NMR. NMR is a promising approach for mechanistic studies of the alarmone-mediated regulation of Rel/RelA because of the high solubility of the (p)ppGpp-regulated NTD fragment. ${ }^{12}$ Using native pppGpp in these experiments would be challenging because of its degradation during long data collection sessions, and therefore,

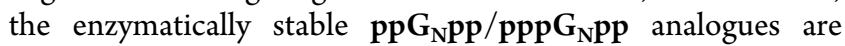
likely to be useful molecular tools for this task. Crystallographic studies of a representative set of RSHs complexes with either $(\mathrm{p}) \mathrm{ppG}_{\mathrm{N}} \mathrm{pp}$ or $(\mathrm{p}) \mathrm{ppA}_{\mathrm{N}} \mathrm{pp}$ have the potential to answer the 


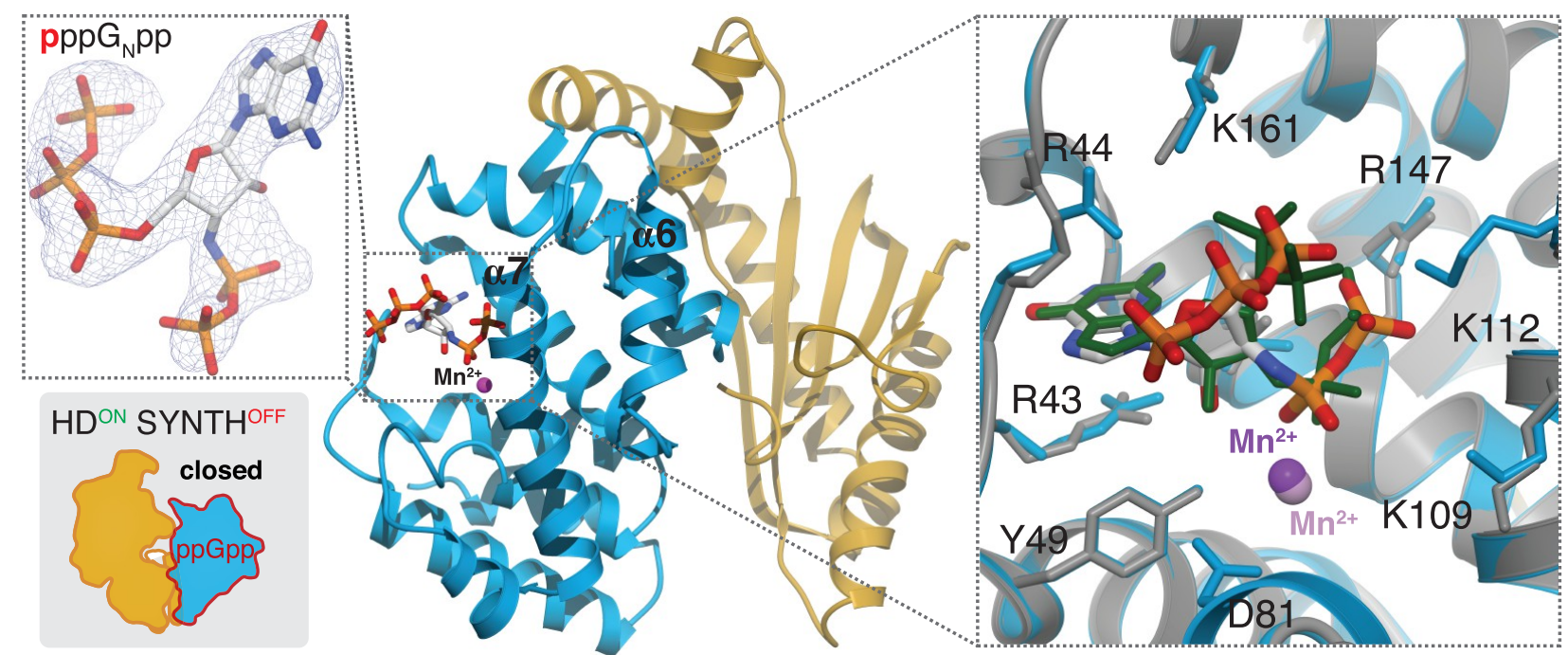

Figure 5. Structure of T. thermophilus Rel NTD complexed with pppGNpp. In the complex (PDBID 7OHG), the nonhydrolysable alarmone analogue specifically binds to the $\mathrm{HD}$ active site and triggers the $\mathrm{HD}^{\mathrm{ON}} \mathrm{SYNTH}{ }^{\mathrm{OFF}}$ conformation of $\operatorname{Rel}_{T t}{ }^{\mathrm{NTD}}$. The HD domain is colored in blue and the SYNTH domain in yellow. Left insert: electron density map representation (blue mesh) of pppGNpp (in atom colors) bound in the HD active site. Right insert: details of the $\operatorname{Rel}_{T t}{ }^{\mathrm{NTD}}$ :pppGNpp binding interface, superimposed on the HD active site of Rel ${ }_{T t}{ }^{\mathrm{NTD}}$ :ppGpp (PDB 6S2T $\mathrm{P}^{15}$; protein in gray, ppGpp in green). The organization of the catalytic residues (labelled) and location of the crucial $\mathrm{Mn}^{2+}$ ion is equivalent in both complexes. The $\mathrm{Mn}^{2+}$ ion from the $\operatorname{Rel}_{T t}{ }^{\mathrm{NTD}}$ :pppGNpp complex is in dark purple and $\mathrm{Mn}^{2+}$ from $\operatorname{Rel}_{T t}^{\text {NTD }}$ :ppGpp complex is in light purple.

question of how the (p)ppGpp/(p)ppApp HD substrate specificity is determined on the molecular level. Finally, the analogues could serve as useful tools for experiments that require the addition of alarmones to enzymatically active complex biological mixtures. For example, nonhydrolyzable analogues could be used in thermal proteome profiling (TPP) experiments to discover new (p)ppGpp/(p)ppApp targets similarly to recent TPP-enabled proteome-wide identification of NTP-binding proteins. ${ }^{43}$

The molecular tools presented in the current study lay the foundation for developing a toolbox for chemical biology studies. First, in addition to GppNHp, which inspired us to develop the $(\mathbf{p}) \mathbf{p p N u} \mathbf{N u}_{\mathrm{N}} \mathbf{p p}$ analogues, two more analogues are commonly used to study GTPases: 5'-guanosyl-methylenetriphosphate (GDPCP) ${ }^{44}$ and $\mathrm{O}$ - $(\gamma$-thio)triphosphate $(\mathrm{GTP} \gamma \mathrm{S}),{ }^{34}$ prompting the development of analogous (p)$\mathrm{ppGpp/(p)ppApp} \mathrm{derivatives.} \mathrm{Second,} \mathrm{nonhydrolysable} \mathrm{ana-}$ logues can serve as a platform for further derivatization at the $2^{\prime}$ position of the sugar part or in positions 2 or 6 of the nucleobase: for cross-linking (e.g., through the diazirine moiety) and fluorescent labels installed via click chemistry to the terminal triple bond.

\section{METHODS}

Organic Synthesis. The experimental procedures for adenosine analogues $\mathbf{2 b}-\mathbf{9 b}$ are presented in the Supporting Information, the procedures for synthesis of guanosine analogues $2 \mathbf{a}-\mathbf{9} \mathbf{a}$ are described below. Unless stated otherwise, all solvents used were anhydrous. TLC was performed on silica gel precoated aluminum plates TLC Silica gel $60 \mathrm{~F}_{254}$ (Merck), and compounds were detected by UV light $(254 \mathrm{~nm})$, by spraying with $1 \%$ solution of ninhydrine to visualize amines, or by spraying with $1 \%$ solution of 4-(4-nitrobenzyl)pyridine in ethanol followed by heating and treating with gaseous ammonia (blue color of mono- and diesters of phosphonic acid, alkylating agents). Conversion rate of reactions as well as purity of prepared compounds was determined by LC-MS performed on Waters Auto Purification System with 2545 Quaternary Gradient Module and 3100 Single Quadrupole Mass Detector using LUNA C18 column
(Phenomenex, $100 \times 4.6 \mathrm{~mm}, 3 \mu \mathrm{m}$ ) at a flow rate of $1 \mathrm{~mL} / \mathrm{min}$. Typical conditions were the following: mobile phase, $\mathrm{A}=50 \mathrm{mM}$ $\mathrm{NH}_{4} \mathrm{HCO}_{3} ; \mathrm{B}=50 \mathrm{mM} \mathrm{NH} \mathrm{HCO}_{3}$ in $50 \%$ aq. $\mathrm{CH}_{3} \mathrm{CN}$; C $\mathrm{CH}_{3} \mathrm{CN} ; \mathrm{A} \rightarrow \mathrm{B} / 10 \mathrm{~min}, \mathrm{~B} \rightarrow \mathrm{C} / 10 \mathrm{~min}, \mathrm{C} / 5 \mathrm{~min}$. Preparative reverse-phase HPLC (rpHPLC) was performed on a LC5000 Liquid Chromatograph (INGOS-PIKRON, CR) using a Luna C18 (2) column $(250 \times 21.2 \mathrm{~mm}, 5 \mu \mathrm{m})$ at a flow rate of $10 \mathrm{~mL} / \mathrm{min}$ by gradient elution of methanol in $0.1 \mathrm{M} \mathrm{TEAB} \mathrm{pH} 7.5(\mathrm{~A}=0.1 \mathrm{M}$ TEAB; $\mathrm{B}=0.1 \mathrm{M}$ TEAB in $50 \%$ aq. methanol; $\mathrm{C}=$ methanol) or without buffer. Final compounds were lyophilized from water. Mass spectra were recorded on LTQ Orbitrap XL (Thermo Fisher Scientific) using ESI ionization. ${ }^{1} \mathrm{H},{ }^{13} \mathrm{C}$, and ${ }^{31} \mathrm{P}$ NMR spectra were acquired on a Bruker AVANCE IIIHD $600\left({ }^{1} \mathrm{H}\right.$ at $600.1 \mathrm{MHz},{ }^{13} \mathrm{C}$ at $150.9 \mathrm{MHz})$, Bruker AVANCE IIIHD $500\left({ }^{1} \mathrm{H}\right.$ at $500.0 \mathrm{MHz},{ }^{13} \mathrm{C}$ at $125.7 \mathrm{MHz},{ }^{31} \mathrm{P}$ at $\left.202.4 \mathrm{MHz}\right)$ and JEOL ECZR $500\left({ }^{1} \mathrm{H}\right.$ at 500.2 $\mathrm{MHz},{ }^{13} \mathrm{C}$ at $125.8 \mathrm{MHz},{ }^{31} \mathrm{P}$ at $202.5 \mathrm{MHz}$ ) spectrometers, as indicated. ${ }^{1} \mathrm{H}$ and ${ }^{13} \mathrm{C}$ resonances were fully assigned using $\mathrm{H}, \mathrm{H}-$ COSY, H,H-ROESY, H,C-HSQC and H,C-HMBC techniques. All chemical shifts are quoted on the $\delta$ scale in ppm and referenced using residual ${ }^{1} \mathrm{H}$ solvent signal in ${ }^{1} \mathrm{H}$ NMR spectra $\left(\delta\left(\mathrm{CHCl}_{3}\right)=7.26\right.$ $\mathrm{ppm} ; \delta\left(\mathrm{C}_{6} \mathrm{HD}_{5}\right)=7.16 \mathrm{ppm} ; \delta\left(\mathrm{CHD}_{2} \mathrm{OD}\right)=3.31 \mathrm{ppm}$; $\left.\delta\left(\mathrm{CHD}_{2} \mathrm{SO}_{2} \mathrm{CD}_{3}\right)=2.50 \mathrm{ppm}\right)$ and ${ }^{13} \mathrm{C}$ solvent signal in ${ }^{13} \mathrm{C}$ NMR spectra $\left(\delta\left(\mathrm{C}_{6} \mathrm{D}_{6}\right)=128.0 \mathrm{ppm} ; \delta\left(\mathrm{CDCl}_{3}\right)=77.0 \mathrm{ppm} ; \delta\left(\mathrm{CD}_{3} \mathrm{OD}\right)=\right.$ $\left.49.0 \mathrm{ppm} ; \delta\left(\mathrm{CD}_{3} \mathrm{SO}_{2} \mathrm{CD}_{3}\right)=39.7 \mathrm{ppm}\right)$. NMR spectra measured in $\mathrm{D}_{2} \mathrm{O}$ were referenced to the signal of $t-\mathrm{BuOH}(10 \% \mathrm{v} / \mathrm{v}$ solution in $\mathrm{D}_{2} \mathrm{O}, 1$ drop) as the internal standard $\left(1.24 \mathrm{ppm}\right.$ in ${ }^{1} \mathrm{H}, 32.43 \mathrm{ppm}$ in $\left.{ }^{13} \mathrm{C}\right) .{ }^{31} \mathrm{P}$ NMR spectra were referenced to $\mathrm{H}_{3} \mathrm{PO}_{4}$ signal $(0 \mathrm{ppm})$ as the external standard in $1 \mathrm{~mm}$ coaxial capillary. Coupling constants $(J)$ are reported in $\mathrm{Hz}$ with the following splitting abbreviations: $\mathrm{s}=$ singlet, $\mathrm{d}=$ doublet, $\mathrm{t}=$ triplet, $\mathrm{q}=$ quartet, $\mathrm{m}=$ multiplet. All intermediates were determined by LC-MS. Purity of prepared compounds was determined by LC-MS. All final compounds were lyophilized from water. Mass spectra were recorded on LTQ Orbitrap XL (Thermo Fisher Scientific) using ESI ionization. Infrared (IR) spectra were recorded on a Thermo Scientific Nicolet 6700 spectrometer. Absorption maxima $\left(\nu_{\max }\right)$ are reported in wavenumbers $\left(\mathrm{cm}^{-1}\right)$. Compounds $\mathbf{2} \mathbf{a}-\mathbf{b}$ were prepared as described elsewhere. ${ }^{37}$

3'-Azido-3'-deoxyguanosine 2a. See Supporting Information.

${ }^{1}$ H NMR (500.0 MHz, DMSO- $d_{6}$ ): 3.55 (ddd, $1 \mathrm{H}, J_{\mathrm{gem}}=12.0$, $\left.J_{5^{\prime} \mathrm{b}, \mathrm{OH}}=5.8, J_{5^{\prime} \mathrm{b}, 4^{\prime}}=3.9, \mathrm{H}-5^{\prime} \mathrm{b}\right) ; 3.62\left(\mathrm{ddd}, 1 \mathrm{H}, J_{\text {gem }}=12.0, J_{5^{\prime} \mathrm{a}, \mathrm{OH}}=\right.$ 
5.2, $\left.J_{5^{\prime} \mathrm{a}, 4^{\prime}}=3.9, \mathrm{H}-5^{\prime} \mathrm{a}\right) ; 3.89\left(\mathrm{q}, 1 \mathrm{H}, J_{4^{\prime}, 5^{\prime}}=3.9, J_{4^{\prime}, 3^{\prime}}=3.9, \mathrm{H}-4^{\prime}\right) ; 4.24$ $\left(\mathrm{dd}, 1 \mathrm{H}, J_{3^{\prime}, 2^{\prime}}=5.5, J_{3^{\prime}, 4^{\prime}}=3.9, \mathrm{H}-3^{\prime}\right) ; 4.80\left(\mathrm{dt}, 1 \mathrm{H}, J_{2^{\prime}, 1^{\prime}}=6.0, J_{2^{\prime}, \mathrm{OH}}=\right.$ $\left.J_{2^{\prime}, 3^{\prime}}=5.5, \mathrm{H}-2^{\prime}\right) ; 5.20\left(\mathrm{dd}, 1 \mathrm{H}, J_{\mathrm{OH}, 5^{\prime}}=5.8,5.2, \mathrm{OH}-5^{\prime}\right) ; 5.70(\mathrm{~d}, 1 \mathrm{H}$, $\left.J_{1^{\prime}, 2^{\prime}}=6.0, \mathrm{H}^{\prime} 1^{\prime}\right) ; 6.19\left(\mathrm{bd}, 1 \mathrm{H}, J_{\mathrm{OH}, 2^{\prime}}=5.5, \mathrm{OH}-2^{\prime}\right) ; 6.51(\mathrm{bs}, 2 \mathrm{H}$, $\mathrm{NH}_{2}$ ); 7.93 (s, 1H, H-8); 10.64 (bs, $1 \mathrm{H}, \mathrm{NH}$ ).

${ }^{13} \mathrm{C}$ NMR $\left(125.7 \mathrm{MHz}\right.$, DMSO-d $\left.d_{6}\right): 61.56\left(\mathrm{CH}_{2}-5^{\prime}\right) ; 62.17(\mathrm{CH}-$ $\left.3^{\prime}\right)$; $74.41\left(\mathrm{CH}-2^{\prime}\right) ; 82.49\left(\mathrm{CH}-4^{\prime}\right) ; 86.52\left(\mathrm{CH}^{\prime} 1^{\prime}\right) ; 116.85$ (C-5); 135.65 (CH-8); 151.47 (C-4); 153.98 (C-2); 156.93 (C-6).

IR $\nu_{\max }(\mathrm{KBr}) 3434$ (vs, br), $3156(\mathrm{~s}, \mathrm{vbr}), 2925(\mathrm{~m}), 2872(\mathrm{w})$, 2111 (s), 1734 (m), 1693 (vs), 1645 (s), 1632 (s), 1601 (s), 1575 (m), $1542(\mathrm{~m}), 1486(\mathrm{~m}), 1394(\mathrm{w}), 1176(\mathrm{w}), 1085(\mathrm{~m}), 1072(\mathrm{~m}$, sh), $1050(\mathrm{w}), 780(\mathrm{w}), 688(\mathrm{w}), 632(\mathrm{w}), 555(\mathrm{w})$.

HR-ESI $\mathrm{C}_{10} \mathrm{H}_{13} \mathrm{O}_{4} \mathrm{~N}_{8}(\mathrm{M}+\mathrm{H})^{+}$calcd 309.10543, found 309.10540 .

3'-Azido-3'-deoxyguanosine 5'-H-Phosphonate $3 a$. Tris(1,1,1,3,3,3-hexafluoropropan-2-yl) phosphite (1.14 g, $2.14 \mathrm{mmol}$ ) was added to the mixture of $3^{\prime}$-azido-3'-deoxyguanosine $(2 \mathrm{a})(0.47 \mathrm{~g}$, $1.5 \mathrm{mmol})$ and DIPEA $(0.37 \mathrm{~mL}, 2.14 \mathrm{mmol})$ in DMF $(20 \mathrm{~mL})$ at 0 ${ }^{\circ} \mathrm{C}$. The reaction mixture was stirred under argon atmosphere at $0{ }^{\circ} \mathrm{C}$ for $1 \mathrm{~h}$. Two M TEAB ( $2 \mathrm{~mL})$ was added, and the reaction mixture was stirred at RT (rt) for $2 \mathrm{~h}$. The reaction mixture was concentrated in vacuo, and desired product was obtained by chromatography on silica gel using a linear gradient of $\mathrm{H} 1$ (ethyl acetate/acetone/ ethanol/water $\approx 4: 1: 1: 1)$ in ethyl acetate in $62 \%$ yield $(0.35 \mathrm{~g}, 0.95$ $\mathrm{mmol}$ ) in the form of colorless amorphous solid.

${ }^{1} \mathrm{H}$ NMR (500.0 MHz, DMSO- $\left.d_{6}\right): 1.15\left(\mathrm{t}, 9 \mathrm{H}, J_{\text {vic }}=7.3\right.$, $\left.\mathrm{CH}_{3} \mathrm{CH}_{2} \mathrm{~N}\right) ; 3.02\left(\mathrm{q}, 6 \mathrm{H}, J_{\text {vic }}=7.3, \mathrm{CH}_{3} \mathrm{CH}_{2} \mathrm{~N}\right) ; 3.83\left(\right.$ ddd, $1 \mathrm{H}, J_{\text {gem }}$ $\left.=11.5, J_{\mathrm{H}, \mathrm{P}}=7.5, J_{5^{\prime} \mathrm{b}, 4^{\prime}}=4.2, \mathrm{H}-5^{\prime} \mathrm{b}\right) ; 3.90\left(\mathrm{ddd}, 1 \mathrm{H}, J_{\mathrm{gem}}=11.5, J_{\mathrm{H}, \mathrm{P}}\right.$ $\left.=8.1, J_{5^{\prime} \mathrm{a}, 4^{\prime}}=4.2, \mathrm{H}-5^{\prime} \mathrm{a}\right) ; 3.98\left(\mathrm{td}, 1 \mathrm{H}, J_{4^{\prime}, 5^{\prime}}=4.2, J_{4^{\prime}, 3^{\prime}}=2.8, \mathrm{H}-4^{\prime}\right)$; $4.34\left(\mathrm{dd}, 1 \mathrm{H}, J_{3^{\prime}, 2^{\prime}}=5.5, J_{3^{\prime}, 4^{\prime}}=2.8, \mathrm{H}-3^{\prime}\right) ; 4.97\left(\mathrm{ddd}, 1 \mathrm{H}, J_{2^{\prime}, 1^{\prime}}=6.7\right.$, $\left.J_{2^{\prime}, 3^{\prime}}=5.5, J_{2^{\prime}, \mathrm{OH}}=5.3, \mathrm{H}-2^{\prime}\right) ; 5.70\left(\mathrm{~d}, 1 \mathrm{H}, J_{1^{\prime}, 2^{\prime}}=6.7, \mathrm{H}-1^{\prime}\right) ; 6.27(\mathrm{bd}$, $\left.1 \mathrm{H}, J_{\mathrm{OH}, 2^{\prime}}=5.3, \mathrm{OH}-2^{\prime}\right) ; 6.63\left(\mathrm{~d}, 1 \mathrm{H}, J_{\mathrm{H}, \mathrm{P}}=587.6, \mathrm{HP}\right) ; 7.97(\mathrm{~s}, 1 \mathrm{H}$, $\mathrm{H}-8) ; 10.80(\mathrm{bs}, 1 \mathrm{H}, \mathrm{NH})$.

${ }^{13} \mathrm{C}$ NMR (125.7 MHz, DMSO- $\left.d_{6}\right): 8.62\left(\mathrm{CH}_{3} \mathrm{CH}_{2} \mathrm{~N}\right) ; 45.48$ $\left(\mathrm{CH}_{3} \mathrm{CH}_{2} \mathrm{~N}\right) ; 62.97\left(\mathrm{CH}-3^{\prime}\right) ; 63.10\left(\mathrm{~d}, J_{\mathrm{C}, \mathrm{P}}=4.3, \mathrm{CH}_{2}-5^{\prime}\right) ; 73.94$ $\left(\mathrm{CH}-2^{\prime}\right) ; 81.40\left(\mathrm{~d}, J_{\mathrm{C}, \mathrm{P}}=6.7, \mathrm{CH}-4^{\prime}\right) ; 86.48\left(\mathrm{CH}-1^{\prime}\right) ; 116.82(\mathrm{C}-5)$; 136.02 (CH-8); 151.65 (C-4); 154.05 (C-2); 156.98 (C-6).

${ }^{31} \mathbf{P}\left[{ }^{1} \mathbf{H}\right]$ NMR $\left(202.4 \mathrm{MHz}\right.$, DMSO- $\left.d_{6}\right): 2.55$.

IR $\nu_{\text {max }}(\mathrm{KBr}) 3432$ (s, br), 3166 (m, br), 3130 (m, br, sh), 2753 (w, br), 2690 (w, br), 2491 (w, br), 2363 (w, br), 2109 (s), 1693 (vs), $1636(\mathrm{~s}), 1609(\mathrm{~s}), 1572(\mathrm{~m}), 1537(\mathrm{~m}), 1484(\mathrm{~m}), 1424(\mathrm{w}), 1388$ (w), $1316(\mathrm{w}), 1219(\mathrm{~s}), 1063(\mathrm{~m}), 1047$ (m, sh), $1017(\mathrm{w}), 980(\mathrm{~m})$, $783(\mathrm{~m}), 674(\mathrm{w}), 639(\mathrm{w}), 559(\mathrm{~m})$.

HR-ESI $\mathrm{C}_{10} \mathrm{H}_{12} \mathrm{O}_{6} \mathrm{~N}_{8} \mathrm{P}(\mathrm{M}-\mathrm{H})^{-}$calcd 371.06229, found 371.06251. 3'-Azido-3'-deoxyguanosine 5'-Diphosphate 4a. Compound 3a $(0.35 \mathrm{~g}, 0.94 \mathrm{mmol})$ was rendered anhydrous by coevaporating with toluene $(2 \times 30 \mathrm{~mL})$ and suspended in $\mathrm{MeCN}(10 \mathrm{~mL})$. Trimethylsilylmorpholine $(0.75 \mathrm{~g}, 5 \mathrm{mmol})$ was added to the suspension, and the reaction mixture was stirred under argon atmosphere for $1 \mathrm{~h}$ at rt. Tetrachloromethane $(2.27 \mathrm{~mL}, 24 \mathrm{mmol})$ was added, and the reaction mixture was stirred at $\mathrm{rt}$ under argon atmosphere for additional $2 \mathrm{~h}$. $0.5 \mathrm{M}$ solution of tris(tributylammonium) phosphate $(9.5 \mathrm{~mL})$ was added, and the reaction mixture was stirred under argon atmosphere at $50{ }^{\circ} \mathrm{C}$ overnight. The reaction mixture was concentrated in vacuo (oil pump vacuum, at temperature below $40{ }^{\circ} \mathrm{C}$ ), the residue was dissolved in water $(250 \mathrm{~mL})$ and applied on a column of Poros HQ50. The product was obtained by a linear gradient of $0.6 \mathrm{M}$ TEAB in water. Fractions containing product (according to LCMS analysis) were concentrated in vacuo and coevaporated with $\mathrm{MeOH}(3 \times 50 \mathrm{~mL})$ to remove TEAB affording desired product $\mathbf{4 a}$ as triethylammonium salt in $43 \%$ yield $(311 \mathrm{mg}, 0.4 \mathrm{mmol})$ in the form of amorphous solid.

${ }^{1} \mathrm{H}$ NMR $\left(500.0 \mathrm{MHz}, \mathrm{D}_{2} \mathrm{O}\right): 4.21\left(\mathrm{dd}, 2 \mathrm{H}, J_{\mathrm{H}, \mathrm{P}}=5.4, J_{5^{\prime}, 4^{\prime}}=3.3\right.$, $\left.\mathrm{H}-5^{\prime}\right) ; 4.36\left(\mathrm{dtd}, 1 \mathrm{H}, J_{4^{\prime}, 3^{\prime}}=3.6, J_{4^{\prime}, 5^{\prime}}=3.3, J_{\mathrm{H}, \mathrm{P}}=1.8, \mathrm{H}-4^{\prime}\right) ; 4.58(\mathrm{dd}$, $\left.1 \mathrm{H}, J_{3^{\prime}, 2^{\prime}}=5.7, J_{3^{\prime}, 4^{\prime}}=3.6, \mathrm{H}-3^{\prime}\right) ; 5.04\left(\mathrm{dd}, 1 \mathrm{H}, J_{2^{\prime}, 1^{\prime}}=6.3, J_{2^{\prime}, 3^{\prime}}=5.7\right.$, $\left.\mathrm{H}-2^{\prime}\right) ; 5.88\left(\mathrm{~d}, 1 \mathrm{H}, J_{1^{\prime}, 2^{\prime}}=6.3, \mathrm{H}-1^{\prime}\right) ; 8.11(\mathrm{~s}, 1 \mathrm{H}, \mathrm{H}-8)$.

${ }^{13} \mathrm{C}$ NMR (125.7 MHz, $\left.\mathrm{D}_{2} \mathrm{O}\right): 64.93\left(\mathrm{CH}-3^{\prime}\right) ; 67.97\left(\mathrm{~d}, J_{\mathrm{C}, \mathrm{P}}=5.2\right.$, $\left.\mathrm{CH}_{2}-5^{\prime}\right) ; 76.98\left(\mathrm{CH}-2^{\prime}\right) ; 84.66\left(\mathrm{~d}, J_{\mathrm{C}, \mathrm{P}}=9.1, \mathrm{CH}-4^{\prime}\right) ; 89.39(\mathrm{CH}-$ $\left.1^{\prime}\right)$; 118.97 (C-5); 140.32 (CH-8); 154.60 (C-4); 156.77 (C-2); $161.73(\mathrm{C}-6)$.
${ }^{31} \mathbf{P}\left[{ }^{1} \mathbf{H}\right]$ NMR (202.4 MHz, $\left.\mathrm{D}_{2} \mathrm{O}\right):-10.90\left(\mathrm{bd}, \mathrm{J}=19.0, \mathrm{P}_{\alpha}\right)$; -7.42 (bd, $\mathrm{J}=19.0, \mathrm{P}_{\beta}$ ).

HR-ESI $\mathrm{C}_{10} \mathrm{H}_{12} \mathrm{O}_{10} \mathrm{~N}_{8} \mathrm{P}_{2}(\mathrm{M}-\mathrm{H})^{-} \mathrm{z}=2$ calcd 233.00813, found 233.00811.

3'-Amino-3'-deoxyguanosine 5'-Diphosphate 5a. Compound 4a $(155 \mathrm{mg}, 0.2 \mathrm{mmol})$ dissolved in water $(10 \mathrm{~mL})$ was hydrogenated in the presence of $\mathrm{Pd} / \mathrm{C}$ catalyst $\left(10 \mathrm{mg}\right.$ ) and excess of $\mathrm{NaHCO}_{3}$ at a pressure of $100 \mathrm{kPa}$ for $5 \mathrm{~h}$. Catalyst was filtered off, the supernatant was concentrated in vacuo and desired product was obtained by preparative HPLC on a reversed-phase using a linear gradient of methanol in $0.1 \mathrm{M} \mathrm{TEAB}$ in $85 \%$ yield $(110 \mathrm{mg}, 170 \mu \mathrm{mol})$ in the form of colorless glass.

${ }^{1} \mathrm{H}$ NMR $\left(500.0 \mathrm{MHz}, \mathrm{D}_{2} \mathrm{O}\right): 1.27\left(\mathrm{t}, 18 \mathrm{H}, J_{\text {vic }}=7.2, \mathrm{CH}_{3} \mathrm{CH}_{2} \mathrm{~N}\right)$; $3.18\left(\mathrm{q}, 12 \mathrm{H}, J_{\text {vic }}=7.2, \mathrm{CH}_{3} \mathrm{CH}_{2} \mathrm{~N}\right) ; 4.28\left(\mathrm{dt}, 1 \mathrm{H}, J_{\text {gem }}=11.2, J_{\mathrm{H}, \mathrm{P}}=\right.$ $\left.J_{5^{\prime} \mathrm{b}, 4^{\prime}}=4.4, \mathrm{H}-5^{\prime} \mathrm{b}\right) ; 4.36\left(\mathrm{ddd}, 1 \mathrm{H}, J_{\mathrm{gem}}=11.2, J_{\mathrm{H}, \mathrm{P}}=5.9, J_{5^{\prime} \mathrm{a}, 4^{\prime}}=3.1\right.$, $\left.\mathrm{H}-5^{\prime} \mathrm{a}\right) ; 4.35\left(\mathrm{dd}, 1 \mathrm{H}, J_{3^{\prime}, 4^{\prime}}=7.9, J_{3^{\prime}, 2^{\prime}}=5.7, \mathrm{H}-3^{\prime}\right) ; 4.56(\mathrm{ddd}, 1 \mathrm{H}$, $\left.J_{4^{\prime}, 3^{\prime}}=7.9, J_{4^{\prime}, 5^{\prime}}=4.4,3.1, \mathrm{H}-4^{\prime}\right) ; 4.88\left(\mathrm{dd}, 1 \mathrm{H}, J_{2^{\prime}, 3^{\prime}}=5.7, J_{2^{\prime}, 1^{\prime}}=1.9\right.$, $\left.\mathrm{H}-2^{\prime}\right) ; 5.94\left(\mathrm{~d}, 1 \mathrm{H}, J_{1^{\prime} 2^{\prime}}=1.9, \mathrm{H}-1^{\prime}\right) ; 7.95(\mathrm{~s}, 1 \mathrm{H}, \mathrm{H}-8)$.

${ }^{13} \mathrm{C}$ NMR (125.7 MHz, $\left.\mathrm{D}_{2} \mathrm{O}\right): 11.04\left(\mathrm{CH}_{3} \mathrm{CH}_{2} \mathrm{~N}\right) ; 49.43$ $\left(\mathrm{CH}_{3} \mathrm{CH}_{2} \mathrm{~N}\right) ; 54.00\left(\mathrm{CH}-3^{\prime}\right) ; 66.54\left(\mathrm{~d}, J_{\mathrm{C}, \mathrm{P}}=4.4, \mathrm{CH}_{2}-5^{\prime}\right) ; 75.80$ $\left(\mathrm{CH}-2^{\prime}\right) ; 82.27\left(\mathrm{~d}, J_{\mathrm{C}, \mathrm{P}}=9.8, \mathrm{CH}-4^{\prime}\right) ; 92.64\left(\mathrm{CH}^{\prime} 1^{\prime}\right) ; 118.96(\mathrm{C}-5)$; 140.30 (CH-8); 153.72 (C-4); 156.50 (C-2); 161.37 (C-6).

${ }^{31} \mathbf{P}\left[{ }^{1} \mathbf{H}\right]$ NMR $\left(202.4 \mathrm{MHz}, \mathrm{D}_{2} \mathrm{O}\right):-9.98,-7.01(2 \times \mathrm{bs})$.

HR-ESI $\mathrm{C}_{10} \mathrm{H}_{15} \mathrm{O}_{15} \mathrm{~N}_{6} \mathrm{P}_{2}(\mathrm{M}-\mathrm{H})^{-}$calcd 441.03249, found 441.03252.

3'-Amino-3'-deoxyguanosine 5'-Diphosphate 3'-diphosphate 6a. EDC $(159.5 \mathrm{mg}, 832.2 \mu \mathrm{mol})$ was added to the mixture of compound 5a (46 mg, $104 \mu \mathrm{mol}), \mathrm{Na}_{4} \mathrm{P}_{2} \mathrm{O}_{7}(415 \mathrm{mg}, 1.56 \mathrm{mmol})$, and 2-morpholinoethane-1-sulfonic acid hydrate (MESH) $(66.5 \mathrm{mg}$, $0.31 \mathrm{mmol})$ in $\mathrm{H}_{2} \mathrm{O}(3 \mathrm{~mL})$. The reaction mixture was stirred at $\mathrm{rt}$ overnight, diluted with water $(250 \mathrm{~mL})$, and applied on a column of Poros $50 \mathrm{HQ}$. The column was eluted by a linear gradient of $1 \mathrm{M}$ $\mathrm{TEAB}$ in $0.1 \mathrm{M}$ TEAB. Fractions containing desired product (according to LCMS) were combined, evaporated, and coevaporated with $\mathrm{MeOH}(6 \times 20 \mathrm{~mL})$ to remove all remaining TEAB. The product was further purified using preparative HPLC on reversed phase using a linear gradient of methanol in $0.1 \mathrm{M}$ TEAB. Fractions containing desired product (according to LCMS) were combined, evaporated, and coevaporated with $\mathrm{MeOH}(3 \times 20 \mathrm{~mL})$ to remove all remaining TEAB. Finally, the product was converted to potassium salt by passing through small column of Dowex 50 in $\mathrm{K}^{+}$form. The final product was obtained by lyophilization from water in the form of a white amorphous fluffy solid in $27 \%$ yield $(23.7 \mathrm{mg}, 28.5 \mu \mathrm{mol})$.

${ }^{1} \mathrm{H}$ NMR $\left(500.0 \mathrm{MHz}, \mathrm{D}_{2} \mathrm{O}\right): 4.07\left(\mathrm{td}, 1 \mathrm{H}, J_{\mathrm{H}, \mathrm{P}}=J_{3^{\prime}, 4^{\prime}}=8.9, J_{3^{\prime}, 2^{\prime}}=\right.$ 5.3, H-3'); 4.14-4.22 (m, 2H, H-4', $\left.5^{\prime} \mathrm{b}\right) ; 4.36$ (m, 1H, H-5'a); 4.63 $\left(\mathrm{dd}, 1 \mathrm{H}, J_{2^{\prime}, 3^{\prime}}=5.3, J_{2^{\prime}, 1^{\prime}}=1.9, \mathrm{H}-2^{\prime}\right) ; 5.95\left(\mathrm{~d}, 1 \mathrm{H}, J_{1^{\prime}, 2^{\prime}}=1.9, \mathrm{H}-1^{\prime}\right)$; 8.07 (bs, $1 \mathrm{H}, \mathrm{H}-8)$.

${ }^{13} \mathrm{C}$ NMR $\left(125.7 \mathrm{MHz}, \mathrm{D}_{2} \mathrm{O}\right): 56.75\left(\mathrm{CH}-3^{\prime}\right) ; 68.44\left(\mathrm{~d}, J_{\mathrm{C}, \mathrm{P}}=5.2\right.$, $\left.\mathrm{CH}_{2}-5^{\prime}\right)$; $76.68\left(\mathrm{CH}-2^{\prime}\right) ; 85.16\left(\mathrm{dd}, J_{\mathrm{C}, \mathrm{P}}=11.5,8.6, \mathrm{CH}-4^{\prime}\right) ; 92.05$ (CH-1'); 119.19 (C-5); 140.74 (CH-8); 154.10 (C-4); 156.73 (C-2); 161.93 (C-6).

${ }^{31} \mathbf{P}\left[{ }^{1} \mathbf{H}\right]$ NMR $\left(202.4 \mathrm{MHz}, \mathrm{D}_{2} \mathrm{O}\right):-10.48\left(\mathrm{~d}, J=20.5, \mathrm{P}_{\alpha}-5^{\prime}\right)$; -10.06 (bd, $\left.J=20.5, \mathrm{P}_{\beta^{-}} 5^{\prime}\right) ;-9.43\left(\mathrm{~d}, J=20.5, \mathrm{P}_{\beta^{-}} 3^{\prime}\right) ;-3.59(\mathrm{~d}, J=$ 20.5, $\left.\mathrm{P}_{\alpha}-3^{\prime}\right)$.

HR-ESI $\mathrm{C}_{10} \mathrm{H}_{17} \mathrm{O}_{16} \mathrm{~N}_{6} \mathrm{P}_{4}(\mathrm{M}-\mathrm{H})^{-}$calcd 600.96570, found 600.96465.

3'-Azido-3'-deoxyguanosine 5'-Triphosphate 7a. Compound 3a $(0.23 \mathrm{~g}, 0.62 \mathrm{mmol})$ was rendered anhydrous by coevaporating with toluene $(2 \times 30 \mathrm{~mL})$ and suspended in $\mathrm{MeCN}(10 \mathrm{~mL})$. Trimethylsilylmorpholine $(0.49 \mathrm{~g}, 3.09 \mathrm{mmol})$ was added to a suspension of compound $3 \mathbf{a}$, and the reaction mixture was stirred under argon atmosphere for $1 \mathrm{~h}$. Tetrachloromethane $(1.5 \mathrm{~mL}, 15.5$ mmol) was added, and the reaction mixture was stirred at $\mathrm{rt}$ under argon atmosphere overnight. $0.5 \mathrm{M}$ solution of tris(tributylammonium) pyrophosphate $(6 \mathrm{~mL})$ was added, and the reaction mixture was stirred under argon atmosphere at $50{ }^{\circ} \mathrm{C}$ for 2 days. The reaction mixture was diluted with sat. aq. ammonia and stirred overnight at RT. The reaction mixture was partially concentrated in vacuo (at temperature below $40{ }^{\circ} \mathrm{C}$ ), dissolved in water $(200 \mathrm{~mL})$ and applied on a column of Poros HQ50. Products 
were obtained by a linear gradient of $0.6 \mathrm{M}$ TEAB in water. Fractions containing desired product (according to LCMS) were concentrated in vacuo and coevaporated with $\mathrm{MeOH}(3 \times 50 \mathrm{~mL})$ to remove TEAB affording desired product $7 \mathbf{a}$ as triethylammonium salt in $13 \%$ yield ( $82 \mathrm{mg}, 78 \mu \mathrm{mol}$ ). Diphosphate $4 \mathrm{a}$ was also isolated as a side product in $33 \%$ yield $(155 \mathrm{mg}, 0.2 \mathrm{mmol})$ both in the form of colorless glass.

${ }^{1} \mathrm{H}$ NMR $\left(500.0 \mathrm{MHz}, \mathrm{D}_{2} \mathrm{O}\right): 1.22\left(\mathrm{t}, 27 \mathrm{H}, J_{\text {vic }}=7.3, \mathrm{CH}_{3} \mathrm{CH}_{2} \mathrm{~N}\right)$; $3.13\left(\mathrm{q}, 18 \mathrm{H}, J_{\text {vic }}=7.3, \mathrm{CH}_{3} \mathrm{CH}_{2} \mathrm{~N}\right) ; 4.18\left(\mathrm{ddd}, 1 \mathrm{H}, J_{\text {gem }}=11.7, J_{\mathrm{H}, \mathrm{P}}=\right.$ $\left.4.7, J_{5^{\prime} \mathrm{b}, 4^{\prime}}=3.2, \mathrm{H}-5^{\prime} \mathrm{b}\right) ; 4.23\left(\mathrm{ddd}, 1 \mathrm{H}, J_{\mathrm{gem}}=11.7, J_{\mathrm{H}, \mathrm{P}}=5.9, J_{5^{\prime} \mathrm{a}, 4^{\prime}}=\right.$ $\left.3.2, \mathrm{H}-5^{\prime} \mathrm{a}\right) ; 4.31$ (td, $\left.1 \mathrm{H}, J_{4^{\prime}, 5^{\prime}}=3.2, J_{4^{\prime}, 3^{\prime}}=3.0, \mathrm{H}-4^{\prime}\right) ; 4.57(\mathrm{dd}, 1 \mathrm{H}$, $\left.J_{3^{\prime}, 2^{\prime}}=5.6, J_{3^{\prime}, 4^{\prime}}=3.0, \mathrm{H}-3^{\prime}\right) ; 5.04\left(\mathrm{dd}, 1 \mathrm{H}, J_{2^{\prime}, 1^{\prime}}=6.8, J_{2^{\prime}, 3^{\prime}}=5.6, \mathrm{H}-\right.$ $\left.2^{\prime}\right)$; $5.84\left(\mathrm{~d}, 1 \mathrm{H}, J_{1^{\prime}, 2^{\prime}}=6.8, \mathrm{H}-1^{\prime}\right) ; 8.10(\mathrm{~s}, 1 \mathrm{H}, \mathrm{H}-8)$.

${ }^{13} \mathrm{C}$ NMR (125.7 MHz, $\left.\mathrm{D}_{2} \mathrm{O}\right): 11.04\left(\mathrm{CH}_{3} \mathrm{CH}_{2} \mathrm{~N}\right) ; 49.38$ $\left(\mathrm{CH}_{3} \mathrm{CH}_{2} \mathrm{~N}\right) ; 65.19\left(\mathrm{CH}-3^{\prime}\right) ; 68.50\left(\mathrm{~d}, J_{\mathrm{C}, \mathrm{P}}=4.7, \mathrm{CH}_{2}-5^{\prime}\right) ; 76.93$ $\left(\mathrm{CH}-2^{\prime}\right) ; 84.68\left(\mathrm{~d}, J_{\mathrm{C}, \mathrm{P}}=9.2, \mathrm{CH}-4^{\prime}\right) ; 89.03\left(\mathrm{CH}-1^{\prime}\right) ; 118.78$ (C-5); 140.25 (CH-8); 154.71 (C-4); 156.77 (C-2); 161.49 (C-6).

${ }^{31} \mathbf{P}\left[{ }^{1} \mathbf{H}\right]$ NMR $\left(202.4 \mathrm{MHz}, \mathrm{D}_{2} \mathrm{O}\right):-22.50(\mathrm{bdd}, J=19.9,18.3$, $\left.\mathrm{P}_{\beta}\right) ;-10.90\left(\mathrm{~d}, J=19.9, \mathrm{P}_{\alpha}\right) ;-9.39\left(\mathrm{bd}, J=18.3, \mathrm{P}_{\gamma}\right)$.

HR-ESI $\mathrm{C}_{10} \mathrm{H}_{14} \mathrm{O}_{13} \mathrm{~N}_{8} \mathrm{P}_{3}$ (M-H) ${ }^{-}$calcd 546.98987, found 546.98865 .

3'-Amino-3'-deoxyguanosine 5'-Triphosphate 8a. Compound $7 \mathrm{a}(155 \mathrm{mg}, 0.2 \mathrm{mmol})$ dissolved in water $(10 \mathrm{~mL})$ was hydrogenated in the presence of $\mathrm{Pd} / \mathrm{C}$ catalyst $(10 \mathrm{mg})$ and an excess of $\mathrm{NaHCO}_{3}$ at a pressure of $100 \mathrm{kPa}$ for $5 \mathrm{~h}$. Catalyst was filtered off and the supernatant was concentrated in vacuo and desired product was obtained by preparative HPLC on reversed phase using a linear gradient of methanol in $0.1 \mathrm{M} \mathrm{TEAB}$ in $80 \%$ yield $(118 \mathrm{mg}, 0.226$ $\mathrm{mmol}$ ) in the form of colorless glass.

${ }^{1} \mathrm{H}$ NMR $\left(500.0 \mathrm{MHz}, \mathrm{D}_{2} \mathrm{O}\right): 1.27\left(\mathrm{t}, 27 \mathrm{H}, J_{\text {vic }}=7.3, \mathrm{CH}_{3} \mathrm{CH}_{2} \mathrm{~N}\right)$; $3.18\left(\mathrm{q}, 18 \mathrm{H}, J_{\text {vic }}=7.3, \mathrm{CH}_{3} \mathrm{CH}_{2} \mathrm{~N}\right) ; 4.34\left(\mathrm{bd}, 1 \mathrm{H}, J_{\text {gem }}=11.2, \mathrm{H}-\right.$ $\left.5^{\prime} \mathrm{b}\right)$; 4.45-4.53 (m, 2H, H-3', $\left.5^{\prime} \mathrm{a}\right) ; 4.57\left(\mathrm{bm}, 1 \mathrm{H}, \mathrm{H}^{\prime} 4^{\prime}\right)$; 4.90 (bm, $\left.1 \mathrm{H}, \mathrm{H}-2^{\prime}\right) ; 5.95\left(\mathrm{~d}, 1 \mathrm{H}, J_{1^{\prime}, 2^{\prime}}=2.2, \mathrm{H}-1^{\prime}\right) ; 8.02(\mathrm{~s}, 1 \mathrm{H}, \mathrm{H}-8)$.

${ }^{13} \mathrm{C}$ NMR (125.7 MHz, $\left.\mathrm{D}_{2} \mathrm{O}\right): 11.01\left(\mathrm{CH}_{3} \mathrm{CH}_{2} \mathrm{~N}\right) ; 49.34$ $\left(\mathrm{CH}_{3} \mathrm{CH}_{2} \mathrm{~N}\right) ; 53.19\left(\mathrm{CH}-3^{\prime}\right) ; 66.73\left(\mathrm{~d}, J_{\mathrm{C}, \mathrm{P}}=4.5, \mathrm{CH}_{2}-5^{\prime}\right) ; 75.64$ $\left(\mathrm{CH}-2^{\prime}\right) ; 82.74\left(\mathrm{~d}, J_{\mathrm{C}, \mathrm{P}}=8.7, \mathrm{CH}-4^{\prime}\right)$; $92.16\left(\mathrm{CH}-1^{\prime}\right) ; 118.80(\mathrm{C}-5)$; 140.23 (CH-8); 153.83 (C-4); 156.57 (C-2); 161.36 (C-6).

${ }^{31} \mathbf{P}\left[{ }^{1} \mathbf{H}\right]$ NMR $\left(202.4 \mathrm{MHz}, \mathrm{D}_{2} \mathrm{O}\right):-21.59\left(\mathrm{bt}, J=17.3, \mathrm{P}_{\beta}\right)$; $-10.73\left(\mathrm{bd}, J=17.3, \mathrm{P}_{\alpha}\right) ;-6.60\left(\mathrm{bd}, J=17.3, \mathrm{P}_{\gamma}\right) \cdot$

HR-ESI $\mathrm{C}_{10} \mathrm{H}_{16} \mathrm{O}_{13} \mathrm{~N}_{6} \mathrm{P}_{3} \quad(\mathrm{M}-\mathrm{H})^{-}$calcd 520.99937, found 520.99946.

3'-Amino-3'-deoxyguanosine 5'-Triphosphate 3'-diphosphate 9a. EDC $(0.25 \mathrm{~g}, 1.3 \mathrm{mmol})$ was added to the mixture of compound 8a (100 mg, $0.19 \mathrm{mmol}), \mathrm{Na}_{4} \mathrm{P}_{2} \mathrm{O}_{7}(1 \mathrm{~g}, 3.76 \mathrm{mmol}$ ), and 2morpholinoethane-1-sulfonic acid hydrate (MESH) (50 mg, 0.234 mmol) in $\mathrm{H}_{2} \mathrm{O}(12 \mathrm{~mL})$. The reaction mixture was stirred at $\mathrm{rt}$ overnight, diluted with water $(80 \mathrm{~mL})$, and applied on a column of Poros $50 \mathrm{HQ}$. The column was eluted by a linear gradient of $1 \mathrm{M}$ $\mathrm{TEAB}$ in $0.1 \mathrm{M}$ TEAB. Fractions containing desired product (according to LCMS) were combined, evaporated, and coevaporated with $\mathrm{MeOH}(6 \times 20 \mathrm{~mL})$ to remove all remaining TEAB. The product was further purified using preparative HPLC on reversed phase using a linear gradient of methanol in 0.1 M TEAB. Fractions containing desired product (according to LCMS) were combined, evaporated, and coevaporated with $\mathrm{MeOH}(3 \times 20 \mathrm{~mL})$ to remove all remaining TEAB. Finally, the product was converted to potassium salt by passing through small column of Dowex 50 in $\mathrm{K}^{+}$form. The final product was obtained by lyophilization from water in the form of white amorphous fluffy solid in $24 \%$ yield $(31.8 \mathrm{mg}, 0.047 \mathrm{mmol})$.

${ }^{1} \mathrm{H}$ NMR $\left(500.0 \mathrm{MHz}, \mathrm{D}_{2} \mathrm{O}\right): 4.02\left(\mathrm{td}, 1 \mathrm{H}, J_{\mathrm{H}, \mathrm{P}}=J_{3^{\prime}, 4^{\prime}}=8.9, J_{3^{\prime}, 2^{\prime}}=\right.$ 5.2, H-3'); 4.19-4.26 (m, 2H, H-4', $\left.5^{\prime} \mathrm{b}\right) ; 4.43$ (m, 1H, H-5'a); 4.62 $\left(\mathrm{dd}, 1 \mathrm{H}, J_{2^{\prime}, 3^{\prime}}=5.2, J_{2^{\prime}, 1^{\prime}}=1.9, \mathrm{H}-2^{\prime}\right) ; 5.95\left(\mathrm{~d}, 1 \mathrm{H}, J_{1^{\prime}, 2^{\prime}}=1.9, \mathrm{H}-1^{\prime}\right)$; 8.16 (bs, $1 \mathrm{H}, \mathrm{H}-8)$.

${ }^{13} \mathrm{C}$ NMR $\left(125.7 \mathrm{MHz}, \mathrm{D}_{2} \mathrm{O}\right): 56.59\left(\mathrm{CH}-3^{\prime}\right) ; 68.54\left(\mathrm{~d}, J_{\mathrm{C}, \mathrm{P}}=5.1\right.$, $\left.\mathrm{CH}_{2}-5^{\prime}\right) ; 76.77\left(\mathrm{~d}, J_{\mathrm{C}, \mathrm{P}}=1.2, \mathrm{CH}-2^{\prime}\right) ; 85.05\left(\mathrm{dd}, J_{\mathrm{C}, \mathrm{P}}=11.1,8.6\right.$, $\left.\mathrm{CH}-4^{\prime}\right)$; $92.02\left(\mathrm{CH}_{-1}^{\prime}\right) ; 118.54(\mathrm{C}-5) ; 140.37(\mathrm{CH}-8) ; 153.76$ (C4); 156.73 (C-2); 161.49 (C-6).

${ }^{31} \mathbf{P}\left[{ }^{1} \mathrm{H}\right]$ NMR $\left(202.4 \mathrm{MHz}, \mathrm{D}_{2} \mathrm{O}\right):-21.85\left(\mathrm{bt}, J=18.6, \mathrm{P}_{\beta^{-}} 5^{\prime}\right)$; $-10.22\left(\mathrm{~d}, J=18.6, \mathrm{P}_{\alpha}-5^{\prime}\right) ;-9.82\left(\mathrm{bd}, J=18.6, \mathrm{P}_{\gamma}-5^{\prime}\right) ;-9.42(\mathrm{~d}, J=$ 20.4, $\left.\mathrm{P}_{\beta^{-}} 3^{\prime}\right) ;-3.32\left(\mathrm{~d}, J=20.4, \mathrm{P}_{\alpha}-3^{\prime}\right)$.
HR-ESI $\mathrm{C}_{10} \mathrm{H}_{18} \mathrm{O}_{19} \mathrm{~N}_{6} \mathrm{P}_{5}$ (M-H) ${ }^{-}$calcd 680.93203, found 680.93110.

Plasmid Construction. Plasmids used in this study are described in the Supplementary Table 1 . The constructs for the production of recombinant Staphylococcus aureus Rel N-terminal domain region, NTD $\left(\operatorname{Rel}_{\text {Sau }}\right.$ NTD), and human MESH1 were synthesized by GenScript (https://www.genscript.com/). Protein expression and purification is described in Supplementary Methods.

Biochemical Assays. E. coli RelA and B. subtilis Rel ${ }^{3} \mathrm{H} p p G p p$ Synthesis Activity. The assays were performed as described earlier. ${ }^{12}$ E. coli RelA $\left(\operatorname{RelA}_{E c}\right)$ and B. subtilis $\operatorname{Rel}\left(\operatorname{Rel}_{B s u}\right){ }^{3} \mathrm{H}$ ppGpp synthesis assays were performed at $37{ }^{\circ} \mathrm{C}$ in the presence of $300 \mu \mathrm{M}{ }^{3} \mathrm{H}$ GDP, 1 mM ATP, $2 \mu \mathrm{M}$ E. coli deacylated tRNA ${ }^{\text {Val }}$ (Chemical Block Ltd.), 30 $\mathrm{nM} \operatorname{RelA}_{E c}$ or $\operatorname{Rel}_{B s u}$ and $0.25 \mu \mathrm{M}$ E. coli or B. subtilis $70 \mathrm{~S}$ initiation complexes programmed with a model mRNA coding for MVF tripeptide (70S IC(MVF)). Enzymatic experiments were performed in HEPES:Polymix buffer ( $5 \mathrm{mM} \mathrm{Mg}^{2+}$ final concentration $\left.{ }^{41}\right)$. ppGpp and pppGpp concentrations are indicated in the figures.

B. subtilis Rel and Human MESH1 ${ }^{3} \mathrm{H}$ pppGpp or ${ }^{3} \mathrm{H}$ ppGpp Hydrolysis Assays. The assays were performed as described earlier. ${ }^{2}$ $\operatorname{Rel}_{B s u}(250 \mathrm{nM}$ as final concentration) and Human MESH1 (100 nM as final concentration) hydrolase activity assay was performed at 37 ${ }^{\circ} \mathrm{C}$ in the presence of either $300 \mu \mathrm{M}{ }^{3} \mathrm{H}$ pppGpp or ${ }^{3} \mathrm{H}$ ppGpp in HEPES:Polymix buffer $\left(5 \mathrm{mM} \mathrm{Mg}^{2+}\right.$ final concentration, additionally supplemented with $\left.1 \mathrm{mM} \mathrm{Mn^{2+ }}\right)$.

Protein Crystallization. S. aureus $\operatorname{Rel} N T D\left(\operatorname{Rel}_{\text {Sau }}{ }^{N T D}\right)$. The cleaved $\operatorname{Rel}_{\text {Sau }}{ }_{\text {NTD }}$ protein was concentrated for crystallization to $\approx 10$ $\mathrm{mg} \mathrm{mL} \mathrm{m}^{-1}$. The concentration of the protein solution was measured spectrophotometrically at $280 \mathrm{~nm}$ using the theoretical extinction coefficient at $280 \mathrm{~nm}$ of the proteins as implemented in the online ProtParam tool. ${ }^{45}$ Crystallization conditions were screened at 20 and $4{ }^{\circ} \mathrm{C}$ by the sitting-drop vapor-diffusion method. The drops were set up in Swiss (MRC) 96-well 2-drop UVP sitting-drop plates with the Mosquito HTS system (TTP Labtech). The drops consisting of 0.1 $\mu \mathrm{L}$ of protein and $0.1 \mu \mathrm{L}$ of precipitant solution were equilibrated to $80 \mu \mathrm{L}$ precipitant solution in the reservoir. Several commercially available screens: Crystal Screen I and II (Hampton research), Helix, Pact Premier, LMB and Morpheus II (Molecular Dimensions) were used to screen for crystallization conditions. Crystals of $\mathrm{Rel}_{S a u}$ NTD were vitrified in liquid $\mathrm{N}_{2}$ in the suitable crystallization condition (LMB condition E1) supplemented with pppGpp (10 mM) and PEG400 (30\%) for cryo-protection during storage and transport prior to X-ray exposure at the synchrotron. X-ray diffraction data was collected at the SOLEIL synchrotron (Gif-sur-Yvette, Paris, France) on the Proxima 1 (PX1) and Proxima 2A (PX2A) beamlines using a PILATUS $6 \mathrm{M}$ detector and an Eiger detector respectively and Id-24 Diamond synchrotron (Oxfordshire, U.K.) using a PILATUS $6 \mathrm{M}$ detector.

T. thermophilus Rel NTD ( $\operatorname{Re}_{T t}^{N T D}$ ). The crystals from $T$. thermophilus Rel NTD ( $\operatorname{Rel}_{T t}{ }^{\mathrm{NTD}}$ ) bound to $\mathrm{pppG}_{\mathrm{N}} \mathrm{pp}$ grew in 2.5 $\mathrm{M} \mathrm{Na}$ formate incubated at $20{ }^{\circ} \mathrm{C}$. The drops were set up in Swiss (MRC) 96-well 2-drop UVP sitting-drop plates with the Mosquito HTS system (TTP Labtech). The drops consisting of $0.1 \mu \mathrm{L}$ of protein and $0.1 \mu \mathrm{L}$ of precipitant solution were equilibrated to $80 \mu \mathrm{L}$ of precipitant solution in the reservoir. Cryo-protecting the crystals before harvesting, the nucleotide was also added to the suitable cryoprotecting solution before vitrification in liquid $\mathrm{N}_{2}$ for storage and transport prior to X-ray exposure in the synchrotron. X-ray diffraction data was collected at the SOLEIL synchrotron (Gif-sur-Yvette, Paris, France) on the Proxima 1 (PX1) and Proxima 2A (PX2A) beamlines using a PILATUS $6 \mathrm{M}$ detector and an Eiger detector respectively and Id-24 Diamond synchrotron (Oxfordshire, U.K.) using a PILATUS 6 $\mathrm{M}$ detector. Details of the X-ray data collection and refinement statistics are summarized in Supplementary Table 2.

Structure Determination. The data from the $\operatorname{Rel}_{\text {Sau }}{ }^{\mathrm{NTD}}$ :pppGpp crystals were processed with the XDS suite ${ }^{46}$ and scaled with XSCALE or Aimless. In all cases, the unit-cell content was estimated with the program MATTHEW COEF from the CCP4 program suite. ${ }^{47}$ Molecular replacement was performed with Phaser. ${ }^{48}$ The crystals of the $\operatorname{Rel}_{\text {Sau }}$ NTD diffracted on average to $\approx 2.63 \mathrm{~A}^{\circ}$. 
Coordinates of $\operatorname{Rel}_{T t}{ }_{\text {NTD }}$ (PDBID 6S2 V) were used as a search model. The MR solution from Phaser was used in combination with Rosetta as implemented in the MR-Rosetta ${ }^{49}$ suit from the Phenix package. ${ }^{50}$ MR-Rosetta could trace entirely the HD-domain and $70 \%$ of the SYNTH-domain. After several iterations of manual building with $\mathrm{Coot}^{51}$ and maximum likelihood refinement as implemented in Buster/TNT, ${ }^{52}$ the model was extended to cover all the residues (R/ Rfree of $21.1 \% / 26.5 \%$ ).

In the case of the $\operatorname{Rel}_{T t}{ }^{\mathrm{NTD}}$ :pppG $\mathrm{G}_{\mathrm{N}} \mathrm{pp}$ complex, we used Phaser for molecular replacement using the coordinates of $\mathrm{Rel}_{T t}{ }_{T}^{\mathrm{NTD}}$ (PDBID 6S2 $\mathrm{V})$ as a search model. The initial MR solution from Phaser was used in combination with the simulated annealing refinement protocol implemented in phenix.refine from the Phenix package. ${ }^{50}$ After several iterations of manual building with $\operatorname{Coot}^{51}$ and maximum likelihood refinement as implemented in Buster/TNT, ${ }^{52}$ the model was completed to an $\mathrm{R} / \mathrm{R}$ free of $21.1 \% / 24.2 \%$. The geometrical restraints of all small molecules were generated with the grade Web Server (http://grade.globalphasing.org). ${ }^{53}$ Because of the anisotropic nature of the data from all the crystals of $\operatorname{Rel}_{T t}{ }^{\mathrm{NTD}}: \mathrm{pppG}_{\mathrm{N}} \mathrm{pp}$, we performed anisotropic cutoff and correction of the merged intensity data as implemented on the STARANISO server (http://staraniso. globalphasing.org/) using the DEBYE and STARANISO programs. The analysis of the data suggested a resolution of $2.51 \mathrm{~A}^{\circ}$ (with $3.3 \mathrm{~A}^{\circ}$ in $\mathrm{a}^{*}, 3.3$ in $\mathrm{b}^{*}$ and 2.5 in $\left.\mathrm{c}^{*}\right)$. Details all the X-ray data collection and refinement statistics are summarized in (Supplementary Table 2).

Isothermal Titration Calorimetry, ITC. ITC experiments were carried out on an Affinity ITC instrument (TA Instruments). Nucleotides were diluted into matching protein buffer from 100 $\mathrm{mM}$ solutions and were injected at different temperatures $\left(20^{\circ} \mathrm{C}\right)$ in $200-220 \mathrm{~s}$ intervals. With each injection, $2 \mu \mathrm{L}$ of the nucleotide sample was injected to the purified protein in the measuring cell (with exception of the first injection which was $0.4 \mu \mathrm{L}$ ). The experiments were performed at a stirring rate of $75 \mathrm{rpm}$ in $220 \mathrm{~s}$ intervals in 50 $\mathrm{mM}$ Hepes pH 7.5, $500 \mathrm{mM} \mathrm{KCl}, 500 \mathrm{mM} \mathrm{NaCl}, 10 \mathrm{mM} \mathrm{MgCl}, 1$ $\mathrm{mM}$ TCEP and $0.002 \%$ mellitic acid. Final concentrations were determined by their absorbance at $254 \mathrm{~nm}$ as measured with a NanoDrop device (Thermo fisher Scientific). Proteins were concentrated by ultrafiltration Amicon Ultra (Millipore) centrifugal filter (cutoff: $30 \mathrm{kDa}$ ) at $3000 \mathrm{~g}$ at $15{ }^{\circ} \mathrm{C}$ and final concentrations $(35-40 \mu \mathrm{M})$ were determined by their absorbance at $280 \mathrm{~nm}$ as measured with a NanoDrop device (Thermo fisher Scientific). For all measurements, the titrant was used at a concentration between 15 and 20 -fold that of the protein sample in the ITC cell. All samples were preheated to the measurement temperature and degassed prior to loading the instrument. Data analysis and modeling were performed with NanoAnalyze (TA Instruments) and the Origin package. All of the presented titrations are background-subtracted.

\section{ASSOCIATED CONTENT}

\section{(5) Supporting Information}

The Supporting Information is available free of charge at https://pubs.acs.org/doi/10.1021/acschembio.1c00398.

Synthesis of azidonucleosides via Route I and Route II (detailed description and experimental procedures); protein expression and purification; plasmids used in this work; data collection and processing; copies of ${ }^{1} \mathrm{H}$, ${ }^{13} \mathrm{C}$, and ${ }^{31} \mathrm{P}$ NMR spectra of synthetic intermediates and products (PDF)

\section{Accession Codes}

All the structures have been deposited in the PDB database with the following accession numbers: 7OIW, $7 \mathrm{OHG}$.

\section{AUTHOR INFORMATION}

\section{Corresponding Authors}

Abel Garcia-Pino - Cellular and Molecular Microbiology,

Faculté des Sciences, Université libre de Bruxelles, 1050
Brussels, Belgium; WELBIO, 1200 Brussels, Belgium;

Email: abel.garcia.pino@ulb.be

Vasili Hauryliuk - Laboratory for Molecular Infection Medicine Sweden (MIMS) and Umea ${ }^{\circ}$ Centre for Microbial Research (UCMR), Umeå University, 90187 Ume̊a, Sweden; University of Tartu, Institute of Technology, 50411 Tartu, Estonia; Department of Experimental Medical Science,

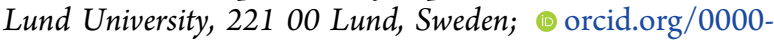
0003-2389-5057; Email: vasili.hauryliuk@med.lu.se

Dominik Rejman - Institute of Organic Chemistry and Biochemistry, Czech Academy of Sciences, 16610 Prague 6, Czech Republic; 이이. ord.org/0000-0001-5977-5001; Email: rejman@uochb.ca.cz

\section{Authors}

Viktor Mojr - Institute of Organic Chemistry and Biochemistry, Czech Academy of Sciences, 16610 Prague 6, Czech Republic

Mohammad Roghanian - Laboratory for Molecular Infection Medicine Sweden (MIMS) and Umea ${ }^{\circ}$ Centre for Microbial Research (UCMR), Umea University, 90187 Umeå, Sweden; Department of Clinical Microbiology, Rigshospitalet, 2200 Copenhagen, Denmark

Hedvig Tamman - Cellular and Molecular Microbiology, Faculté des Sciences, Université libre de Bruxelles, 1050 Brussels, Belgium; WELBIO, 1200 Brussels, Belgium

Duy Dinh Do Pham - Institute of Organic Chemistry and Biochemistry, Czech Academy of Sciences, 16610 Prague 6, Czech Republic

Magdalena Petrová - Institute of Organic Chemistry and Biochemistry, Czech Academy of Sciences, 16610 Prague 6, Czech Republic

Radek Pohl - Institute of Organic Chemistry and Biochemistry, Czech Academy of Sciences, 16610 Prague 6, Czech Republic

Hiraku Takada - Laboratory for Molecular Infection Medicine Sweden (MIMS) and Umea ${ }^{\circ}$ Centre for Microbial Research (UCMR), Umea University, 90187 Umeå, Sweden; Faculty of Life Sciences, Kyoto Sangyo University, Kyoto 603-8555, Japan

Katleen Van Nerom - Cellular and Molecular Microbiology, Faculté des Sciences, Université libre de Bruxelles, 1050 Brussels, Belgium; WELBIO, 1200 Brussels, Belgium

Hanna Ainelo - Cellular and Molecular Microbiology, Faculté des Sciences, Université libre de Bruxelles, 1050 Brussels, Belgium; WELBIO, 1200 Brussels, Belgium

Julien Caballero-Montes - Cellular and Molecular Microbiology, Faculté des Sciences, Université libre de Bruxelles, 1050 Brussels, Belgium; WELBIO, 1200 Brussels, Belgium

Steffi Jimmy - Laboratory for Molecular Infection Medicine Sweden (MIMS) and Umea ${ }^{\circ}$ Centre for Microbial Research (UCMR), Umeå University, 90187 Umeå, Sweden; Deutsches Elektronen-Synchrotron DESY, Centre for Structural Systems Biology (CSSB), 22607 Hamburg, Germany

Complete contact information is available at: https://pubs.acs.org/10.1021/acschembio.1c00398

\footnotetext{
Author Contributions

(V.M., M.R., H.T., D.D.D.P.) These authors contributed equally to this work.
} 


\section{Author Contributions}

V.M. performed experiments (synthesis); M.R. performed experiments (biochemistry); He.T. performed experiments (Xray crystallography); D.D.D.P. performed experiments (synthesis); M.P. performed experiments (synthesis); R.P. performed NMR analysis; H.T. performed experiments (biochemistry); K.V.N. performed experiments (X-ray crystallography); H.A. performed experiments (X-ray crystallography); J.C.M. performed experiments (ITC); S.J. performed experiments (biochemistry); A.G.P. supervised experiments (X-ray crystallography and ITC), wrote original draft (supporting); V.H. supervised experiments (biochemistry), wrote the original draft; and D.R. supervised experiments (synthesis), designed synthetic strategy, performed experiments (synthesis), wrote original draft (supporting).

\section{Funding}

This work was supported by the funds from European Regional Development Fund through the Centre of Excellence for Molecular Cell Technology (VH 2014-2020.4.01.150013); the Molecular Infection Medicine Sweden (MIMS) (VH); The Estonian Research Council (PRG335 to VH); The Swedish Research Council (Vetenskapsradet; 2017-03783 to $\mathrm{VH}$ ); The Ragnar Söderberg foundation (M23/14 to VH); MIMS Excellence by Choice Postdoctoral Fellowship Programme (postdoctoral grant 2018 to MR); The Czech ministry of Education and Sport (grant number 8F19006 to DR) and the Swedish Research Council (2018-00956 to VH) within the RIBOTARGET consortium under the framework of JPIAMR; Umea ${ }^{\circ}$ Centre for Microbial Research (UCMR) (postdoctoral grant 2017 to HT); the Fonds National de Recherche Scientifique (FRFS-WELBIO CR-2017S-03, FNRS CDR J.0068.19 and FNRS-PDR T.0066.18 to AGP); ERC (CoG DiStRes, $\mathrm{n}^{\circ} 864311$ to AGP), the JPIAMR grant JPIEC-AMR-R.8004.18 (Anti-Persistence) to AGP; the Program Actions de Recherche Concerté 2016-2021, Fonds d'Encouragement à la Recherche of ULB (AGP); Fonds Jean Brachet and the Fondation Van Buuren (AGP); the Fund for Research in Industry and Agronomy (KVN and JCM); Chargé de Recherches fellowship from the FNRS $n^{\circ}$ CR/DM-392 (HeT).

\section{Notes}

The authors declare no competing financial interest.

\section{ACKNOWLEDGMENTS}

We acknowledge the use of beamtime at the synchrotron beamlines PROXIMA 1 and PROXIMA 2A, Soleil (Gif-surYvette, France) and thank the beamline staff for their support. Materials availability: (p) $\mathrm{ppNu}_{\mathrm{N}} \mathrm{pp}$ alarmone analogues $\mathbf{6 a} \mathbf{a} \mathbf{b}$ and $\mathbf{9 a}-\mathbf{b}$ generated in this study will be made available on request, but we may require a payment and/or a completed material transfer agreement if there is potential for commercial application.

\section{REFERENCES}

(1) Hauryliuk, V.; Atkinson, G. C.; Murakami, K. S.; Tenson, T.; Gerdes, K. Recent functional insights into the role of (p)ppGpp in bacterial physiology. Nat. Rev. Microbiol. 2015, 13, 298-309.

(2) Irving, S. E.; Choudhury, N. R.; Corrigan, R. M. The stringent response and physiological roles of (pp)pGpp in bacteria. Nat. Rev. Microbiol. 2021, 19, 256-271.

(3) Field, B. Green magic: regulation of the chloroplast stress response by (p)ppGpp in plants and algae. J. Exp. Bot. 2018, 69, 2797-2807.
(4) Liu, K.; Bittner, A. N.; Wang, J. D. Diversity in (p)ppGpp metabolism and effectors. Curr. Opin. Microbiol. 2015, 24, 72-79.

(5) Atkinson, G. C.; Tenson, T.; Hauryliuk, V. The RelA/SpoT homolog (RSH) superfamily: distribution and functional evolution of ppGpp synthetases and hydrolases across the tree of life. PLoS One 2011, 6, e23479.

(6) Mittenhuber, G. Comparative genomics and evolution of genes encoding bacterial (p)ppGpp synthetases/hydrolases (the Rel, RelA and SpoT proteins). J. Mol. Microbiol Biotechnol 2001, 3, 585-600.

(7) Steinchen, W.; Zegarra, V.; Bange, G. (p)ppGpp: Magic Modulators of Bacterial Physiology and Metabolism. Front. Microbiol. 2020, 11, 2072.

(8) Haseltine, W. A.; Block, R. Synthesis of guanosine tetra- and pentaphosphate requires the presence of a codon-specific, uncharged transfer ribonucleic acid in the acceptor site of ribosomes. Proc. Natl. Acad. Sci. U. S. A. 1973, 70, 1564-1568.

(9) Avarbock, D.; Avarbock, A.; Rubin, H. Differential regulation of opposing $\operatorname{Rel}_{M t b}$ activities by the aminoacylation state of a tRNA.ribosome.mRNA.Rel ${ }_{M t b}$ complex. Biochemistry 2000, 39, $11640-11648$.

(10) Shyp, V.; Tankov, S.; Ermakov, A.; Kudrin, P.; English, B. P.; Ehrenberg, M.; Tenson, T.; Elf, J.; Hauryliuk, V. Positive allosteric feedback regulation of the stringent response enzyme RelA by its product. EMBO Rep. 2012, 13, 835-839.

(11) Kudrin, P.; Dzhygyr, I.; Ishiguro, K.; Beljantseva, J.; Maksimova, E.; Oliveira, S. R. A.; Varik, V.; Payoe, R.; Konevega, A. L.; Tenson, T.; Suzuki, T.; Hauryliuk, V. The ribosomal A-site finger is crucial for binding and activation of the stringent factor RelA. Nucleic Acids Res. 2018, 46, 1973-1983.

(12) Takada, H.; Roghanian, M.; Caballero-Montes, J.; Van Nerom, K.; Jimmy, S.; Kudrin, P.; Trebini, F.; Murayama, R.; Akanuma, G.; Garcia-Pino, A.; Hauryliuk, V. Ribosome association primes the stringent factor Rel for tRNA-dependent locking in the A-site and activation of (p)ppGpp synthesis. Nucleic Acids Res. 2021, 49, 444457.

(13) Roghanian, M.; Van Nerom, K.; Takada, H.; Caballero-Montes, J.; Tamman, H.; Kudrin, P.; Talavera, A.; Dzhygyr, I.; Ekstrom, S.; Atkinson, G. C.; Garcia-Pino, A.; Hauryliuk, V. (p)ppGpp controls stringent factors by exploiting antagonistic allosteric coupling between catalytic domains. Mol. Cell 2021, 81, 3310.

(14) Hogg, T.; Mechold, U.; Malke, H.; Cashel, M.; Hilgenfeld, R. Conformational antagonism between opposing active sites in a bifunctional RelA/SpoT homolog modulates (p)ppGpp metabolism during the stringent response. Cell 2004, 117, 57-68.

(15) Mechold, U.; Murphy, H.; Brown, L.; Cashel, M. Intramolecular regulation of the opposing (p)ppGpp catalytic activities of $\operatorname{Rel}_{\text {Seq }}$, the Rel/Spo enzyme from Streptococcus equisimilis. J. Bacteriol. 2002, 184, 2878-2888.

(16) Tamman, H.; Van Nerom, K.; Takada, H.; Vandenberk, N.; Scholl, D.; Polikanov, Y.; Hofkens, J.; Talavera, A.; Hauryliuk, V.; Hendrix, J.; Garcia-Pino, A. A nucleotide-switch mechanism mediates opposing catalytic activities of Rel enzymes. Nat. Chem. Biol. 2020, 16, 834-840.

(17) Jimmy, S.; Saha, C. K.; Kurata, T.; Stavropoulos, C.; Oliveira, S. R. A.; Koh, A.; Cepauskas, A.; Takada, H.; Rejman, D.; Tenson, T.; Strahl, H.; Garcia-Pino, A.; Hauryliuk, V.; Atkinson, G. C. A widespread toxin-antitoxin system exploiting growth control via alarmone signaling. Proc. Natl. Acad. Sci. U. S. A. 2020, 117, 10500-10510.

(18) Nanamiya, H.; Kasai, K.; Nozawa, A.; Yun, C. S.; Narisawa, T.; Murakami, K.; Natori, Y.; Kawamura, F.; Tozawa, Y. Identification and functional analysis of novel (p)ppGpp synthetase genes in Bacillus subtilis. Mol. Microbiol. 2008, 67, 291-304.

(19) Sun, D.; Lee, G.; Lee, J. H.; Kim, H. Y.; Rhee, H. W.; Park, S. Y.; Kim, K. J.; Kim, Y.; Kim, B. Y.; Hong, J. I.; Park, C.; Choy, H. E.; Kim, J. H.; Jeon, Y. H.; Chung, J. A metazoan ortholog of SpoT hydrolyzes ppGpp and functions in starvation responses. Nat. Struct. Mol. Biol. 2010, 17, 1188-1194. 
(20) Potrykus, K.; Thomas, N. E.; Bruhn-Olszewska, B.; Sobala, M.; Dylewski, M.; James, T.; Cashel, M. Estimates of Rel $\mathrm{Seq}_{\text {Seq }}$ Mesh1, and $\mathrm{SAH}_{\text {Mex }}$ Hydrolysis of (p)ppGpp and (p)ppApp by Thin Layer Chromatography and NADP/NADH Coupled Assays. Front. Microbiol. 2020, 11, 581271.

(21) Ding, C. C.; Rose, J.; Sun, T.; Wu, J.; Chen, P. H.; Lin, C. C.; Yang, W. H.; Chen, K. Y.; Lee, H.; Xu, E.; Tian, S.; Akinwuntan, J.; Zhao, J.; Guan, Z.; Zhou, P.; Chi, J. T. MESH1 is a cytosolic NADPH phosphatase that regulates ferroptosis. Nat. Metab 2020, 2, 270-277.

(22) Ito, D.; Kawamura, H.; Oikawa, A.; Ihara, Y.; Shibata, T.; Nakamura, N.; Asano, T.; Kawabata, S. I.; Suzuki, T.; Masuda, S. ppGpp functions as an alarmone in metazoa. Commun. Biol. 2020, 3, 671.

(23) Ahmad, S.; Wang, B.; Walker, M. D.; Tran, H. R.; Stogios, P. J.; Savchenko, A.; Grant, R. A.; McArthur, A. G.; Laub, M. T.; Whitney, J. C. An interbacterial toxin inhibits target cell growth by synthesizing (p)ppApp. Nature 2019, 575, 674-678.

(24) Steinchen, W.; Ahmad, S.; Valentini, M.; Eilers, K.; Majkini, M.; Altegoer, F.; Lechner, M.; Filloux, A.; Whitney, J. C.; Bange, G. Dual role of a (p)ppGpp- and (p)ppApp-degrading enzyme in biofilm formation and interbacterial antagonism. Mol. Microbiol. 2021, 115, 1339

(25) Van Nerom, K.; Tamman, H.; Takada, H.; Hauryliuk, V.; Garcia-Pino, A. The Rel stringent factor from Thermus thermophilus: crystallization and X-ray analysis. Acta Crystallogr., Sect. F: Struct. Biol. Commun. 2019, 75, 561-569.

(26) Berchtold, H.; Reshetnikova, L.; Reiser, C. O.; Schirmer, N. K.; Sprinzl, M.; Hilgenfeld, R. Crystal structure of active elongation factor Tu reveals major domain rearrangements. Nature 1993, 365, 126132.

(27) Chook, Y. M.; Blobel, G. Structure of the nuclear transport complex karyopherin-beta2-Ran x GppNHp. Nature 1999, 399, 230237.

(28) Hauryliuk, V.; Hansson, S.; Ehrenberg, M. Cofactor dependent conformational switching of GTPases. Biophys. J. 2008, 95, 17041715.

(29) Paleskava, A.; Konevega, A. L.; Rodnina, M. V. Thermodynamics of the GTP-GDP-operated conformational switch of selenocysteine-specific translation factor SelB. J. Biol. Chem. 2012, 287, 27906-27912.

(30) Wittinghofer, A.; Vetter, I. R. Structure-function relationships of the G domain, a canonical switch motif. Annu. Rev. Biochem. 2011, 80, 943-971.

(31) Atkinson, G. C. The evolutionary and functional diversity of classical and lesser-known cytoplasmic and organellar translational GTPases across the tree of life. BMC Genomics 2015, 16, 78.

(32) Hauryliuk, V.; Zavialov, A.; Kisselev, L.; Ehrenberg, M. Class-1 release factor eRF1 promotes GTP binding by class-2 release factor eRF3. Biochimie 2006, 88, 747-757.

(33) Paleskava, A.; Konevega, A. L.; Rodnina, M. V. Thermodynamic and kinetic framework of selenocysteyl-tRNA ${ }^{\mathrm{Sec}}$ recognition by elongation factor SelB. J. Biol. Chem. 2010, 285, 3014-3020.

(34) Kuhle, B.; Ficner, R. A monovalent cation acts as structural and catalytic cofactor in translational GTPases. EMBO J. 2014, 33, 25472563.

(35) Bookser, B. C.; Raffaele, N. B.; Reddy, K. R.; Fan, K.; Huang, W.; Erion, M. D. Synthesis of $3^{\prime}$-amino-3'-deoxyguanosine and $3^{\prime}$ amino-3'-deoxyxyloguanosine monophosphate HepDirect prodrugs from guanosine. Nucleosides, Nucleotides Nucleic Acids 2009, 28, 969986.

(36) Timoshchuk, V. A.; Hogrefe, R. I.; Vaghefi, M. M. Improved and reliable synthesis of $3^{\prime}$-azido- $2^{\prime}, 3^{\prime}$-dideoxyguanosine derivatives. Nucleosides, Nucleotides Nucleic Acids 2004, 23, 171-181.

(37) Gadthula, S.; Chu, C. K.; Schinazi, R. F. Synthesis and anti-HIV activity of beta-D-3'-azido- $2^{\prime}, 3^{\prime}$-unsaturated nucleosides and beta-D$3^{\prime}$-azido-3'-deoxyribofuranosylnucleosides. Nucleosides, Nucleotides Nucleic Acids 2005, 24, 1707-1727.

(38) Sakatsume, O.; Yamane, H.; Takaku, H.; Yamamoto, N. Use of new phosphonylating and coupling agents in the synthesis of oligodeoxyribonucleotides via the $\mathrm{H}$-phosphonate approach. Nucleic Acids Res. 1990, 18, 3327-3331.

(39) Yoshikawa, M.; Kato, T.; Takenishi, T. A novel method for phosphorylation of nucleosides to 5 '-nucleotides. Tetrahedron Lett. 1967, 8, 5065-5068.

(40) Choi, S. H.; Collins, J. N.; Smith, S. A.; Davis-Harrison, R. L.; Rienstra, C. M.; Morrissey, J. H. Phosphoramidate end labeling of inorganic polyphosphates: facile manipulation of polyphosphate for investigating and modulating its biological activities. Biochemistry 2010, 49, 9935-9941.

(41) Takada, H.; Roghanian, M.; Murina, V.; Dzhygyr, I.; Murayama, R.; Akanuma, G.; Atkinson, G. C.; Garcia-Pino, A.; Hauryliuk, V. The C-Terminal RRM/ACT Domain Is Crucial for Fine-Tuning the Activation of 'Long' RelA-SpoT Homolog Enzymes by Ribosomal Complexes. Front. Microbiol. 2020, 11, 277.

(42) Turnbull, K. J.; Dzhygyr, I.; Lindemose, S.; Hauryliuk, V.; Roghanian, M. Intramolecular Interactions Dominate the Autoregulation of Escherichia coli Stringent Factor RelA. Front. Microbiol. 2019, 10, 1966.

(43) Sridharan, S.; Kurzawa, N.; Werner, T.; Gunthner, I.; Helm, D.; Huber, W.; Bantscheff, M.; Savitski, M. M. Proteome-wide solubility and thermal stability profiling reveals distinct regulatory roles for ATP. Nat. Commun. 2019, 10, 1155.

(44) Voorhees, R. M.; Schmeing, T. M.; Kelley, A. C.; Ramakrishnan, V. The mechanism for activation of GTP hydrolysis on the ribosome. Science 2010, 330, 835-838.

(45) Gasteiger, E.; Gattiker, A.; Hoogland, C.; Ivanyi, I.; Appel, R. D.; Bairoch, A. ExPASy: The proteomics server for in-depth protein knowledge and analysis. Nucleic Acids Res. 2003, 31, 3784-3788.

(46) Kabsch, W. Xds. Acta Crystallogr., Sect. D: Biol. Crystallogr. 2010, 66, 125-132.

(47) Collaborative Computational Project, Number 4. The CCP4 suite: programs for protein crystallography. Acta Crystallogr., Sect. D: Biol. Crystallogr. 1994, 50, 760-763.

(48) McCoy, A. J.; Grosse-Kunstleve, R. W.; Adams, P. D.; Winn, M. D.; Storoni, L. C.; Read, R. J. Phaser crystallographic software. J. Appl. Crystallogr. 2007, 40, 658-674.

(49) Terwilliger, T. C.; Dimaio, F.; Read, R. J.; Baker, D.; Bunkoczi,

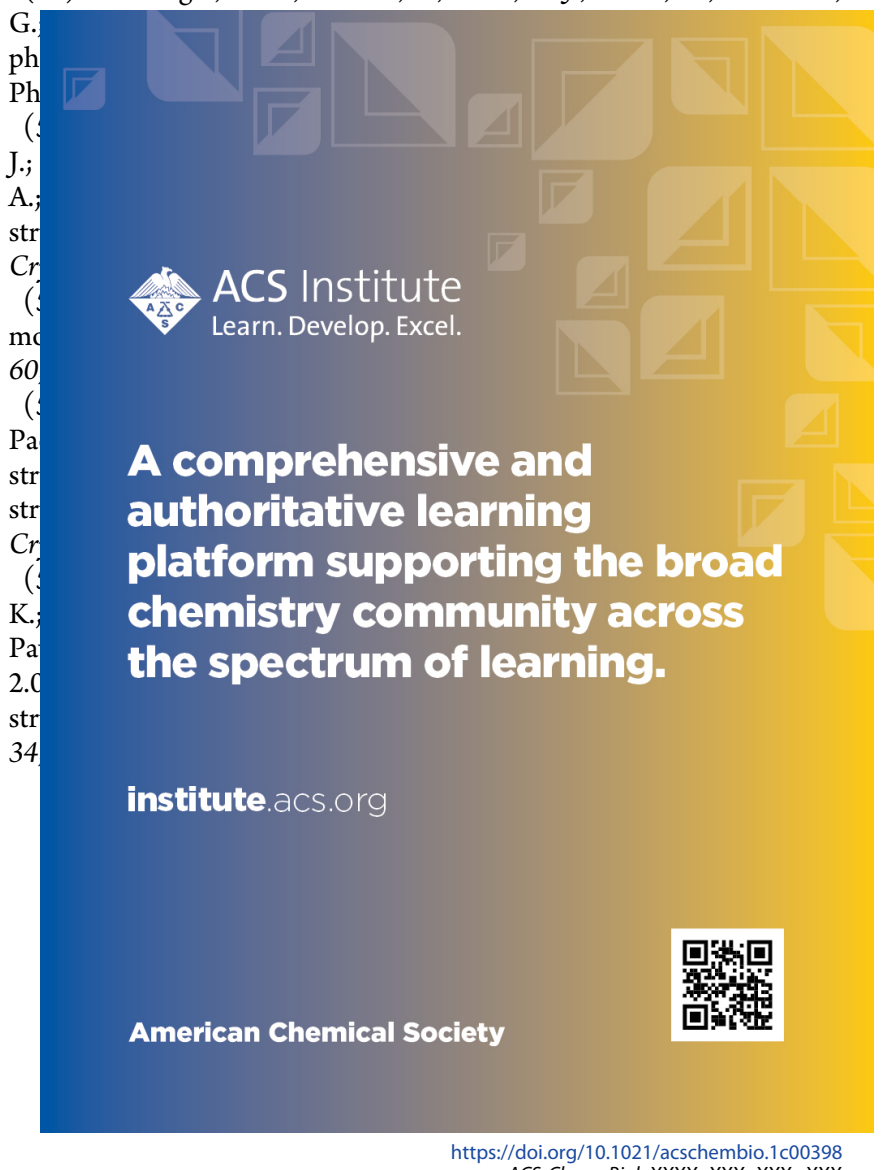

